\title{
Kaum Muda Pecinta Habaib: Kesalehan Populer dan Ekspresi Anak Muda di Ibu Kota
}

SYAMSUL RIJ AL ${ }^{1}$

UIN Syarif Hidayatullah Jakarta

Email: syamsul.rijal@ uinjkt.ac.id

\section{ABSTRACT}

This paper examines the rising popularity of $\mathrm{H}$ adhrami A rab preachers among $M$ uslim youths in contemporary Indonesia. The preachers who claim their descent to theProphet are popularly called as habib (sing.) or habaib (plr.). This study focuses on the late $\mathrm{H}$ abib M unzir al-M usawa and his sermon group, i.e. M ajelis Rasulullah, as well as his young followers in Jakarta. M ajelis Rasulullah is arguably the most popular majelis in Indonesia and has attracted tens of thousands of people in its public preaching. In order to explain its popularity, this study analyses the views and and experiences of his young followers on their participation and activism within the group. It explores both structural and cultural factors that drove young followers to participate in the sermon group. Borrowing Bayat's perspective on M uslim youth and leisure, this paper argues that Indonesian M uslims participate in the habaib dakwah not only for spiritual shelter but also because they see the majelis as sites to express both their piety and their 'youthfulness' in the midst of uncertainty, discontent, and limited spaces for urban youth in Jakarta.

K eywords: Blessing, $\mathrm{H}$ abaib, $\mathrm{H}$ abib M unzir, M ajelis Rasulullah, Youth expression

\section{ABSTRAK}

Artikel ini berupaya menjelaskan menaiknya popularitas penceramah yang berketurunan A rab Hadhramawt (Yaman) di kalangan anak muda Muslim di Indonesia. Penceramah tersebut memiliki silsilah sampai ke Nabi M uhammad SAW. M ereka yang diakui keilmuannya dalam bidang agama dipanggil dengan gelar habib atau habaib (jamak). Beberapa tahun setelah runtuhnya 0 rde Baru, ruang publik Indonesia diramaikan dengan munculnya beberapa habib muda di kota besar, terutama di Jakarta, yang mampu menarik ribuan jamaah. Di antara mereka yang paling populer dan memiliki jemaah terbesar adalah Almarhum H abib Munzir b. Fuad al-Musawa (1973-2013) dengan majelisnya, Majelis Rasulullah. U ntuk menjelaskan popularitasnya, studi ini men ganalisispandangan 
dan pengalaman para jemaahnya ketika masuk dan berkecimpung di Majelis Rasulullah. Studi ini men gkombinasikan analisis struktural dan kultural untuk memahami secara utuh partisipasi anak muda di majelis taklim. Meminjam perspektif Bayat tentang anak muda Muslim di Iran dan di Mesir, artikel ini berargumen bahwa keikutsertaan anak muda di majelishabaib bukan hanya untuk belajar agama dan memperoleh naungan spiritual, namun juga untuk mengekspresikan 'kemudaan' (youthfulness) dengan rekan seusia mereka di tengah kehidupan kota yang penuh masal ah dan tantangan hidup.

Keywords: habaib, $\mathrm{H}$ abib M unzir, M ajelis Rasulullah, berkah, ekspresi anak Muda

\section{PENDAHULUAN}

Salah satu fenomena keagamaan yang menarik di tanah air adalah maraknya pengajian di ruang terbuka di kota-kota besar. Pengajian ini diorganisir oleh habaib muda dengan menggunakan majelis taklim masingmasing. Berbeda dengan pengajian habaib senior yang berlokasi di satu tempat, pengajian habaib muda biasanya berpindah-pindah tempat dan diadakan di ruang terbuka, seperti lapangan Monumen Nasional (Monas), halaman gedung atau rumah, atau jalanan umum yang telah diblokir. Berbagai program kegiatannya telah menarik belasan ribu jemaah dari kalangan remaja dan anak muda di Jakarta dan sekitarnya. Kebanyakan pengikutnya mengendarai sepeda motor dengan mengenakan sarung dan jaket khusus yang bertuliskan nama dan logo majelis. Sebagian berkendara sepeda motor secara konvoy sambil mengibarkan bendera majelis. Di area pengajian, sejumlah anak muda sibuk mengatur arus lalu lintas untuk membantu jemaah yang datang dari berbagai arah. Sebagian dari mereka sibuk mempersiapkan fasilitas majelis seperti audio system, lighting (pencahayaan), kamera video, dan layar putih. Sebagian lainnya sibuk berjaga di pintu masuk sembari membagikan secarik kertas yang berisi materi hadits kepada jemaah yang datang.

Pemandangan di atas menggambarkan partisipasi anak-anak muda di pengajian tradisional yang dipimpin oleh habaib. M enariknya, pengajian tersebut marak di kota-kota besar yang identik dengan simbol kesuksesan materi, konsumerisme, dan modernitas. Jika dahulu, majelis taklim didominasi oleh jemaah dewasa, terutama ibu-ibu, saat ini mayoritas jemaah majelis didominasi oleh anak-anak muda. Hal ini adalah ekspresi keberagamaan unik yang baru muncul pasca Orde Baru. Untuk memahami fenomena ini, artikel ini mengajukan beberapa pertanyaan: M engapa anak 
muda kota mengikuti majelis taklim? Apa daya tarik habaib dan majelisnya bagi kalangan anak muda urban?

Studi terhadap anak muda Muslim di Indonesia telah banyak ditulis dengan beragam perspektif. Sebagian penulis telah menganalisis keikutsertaan anak muda dalam gerakan dan aktivisme Islam serta pengaruhnya terhadap mereka. ${ }^{2}$ Sebagian besar perhatian mereka tertuju pada gerakan Islam transnasional seperti Hizbut Tahrir Indonesia, Gerakan Tarbiyah dengan PKS-nya, Jama'ah Tablig, dan gerakan Salafi. Tetapi, hanya ada sedikit tulisan tentang gerakan traditionalis, seperti majelis habaib. Karya Arif Zamhari, Julia Day Howell, dan Ismail Fajrie Alatas adalah segelintir contoh. Mereka memotret maraknya majelis zikir para habaib di Jakarta sebagai bagian dari perkembangan gerakan tasawuf di tanah air. Keberhasilan majelis ini, menurut Zamhari dan Howell, tidak lepas dari kreatifitas para pemimpinnya yang membawa gerakan sufi ini ke "jalanan" yang sifatnya terbuka, sehingga bisa diikuti oleh berbagai kalangan. ${ }^{3}$ Sementara itu, Alatas melihat terjadinya pergeseran pola majelis zikir di ibu kota sebagai upaya adaptasi para habaib dalam mempertahankan gerakan tarekat seiring dengan terjadinya kebangkitan Islam (Islamic revival) di Indonesia pasca Orde Baru. ${ }^{4}$ Meskipun penulis setuju dengan analisisanalisis tersebut, namun studi mereka lebih terkonsentrasi pada level elit agama (habaib), sehingga kurang menggali lebih jauh suara anak muda dalam kaitannnya dengan partisipasi dan kontribusi mereka pada majelis. Artikel ini berupaya mengisi kekosongan studi tersebut dengan menganalisis suara anak muda pengikutnya, juga perasaan dan pengalaman mereka selama berkecimpung di majelis. Terinspirasi dengan karya Asef Bayat tentang kaum muda M uslim di Iran dan M esir, artikel ini berargumen bahwa keikutsertaan anak muda dalam majelis habaib bukan hanya semata-mata untuk mencari ilmu agama dan spiritualitas, tetapi juga karena mereka melihat majelis sebagai wadah untuk mengekspresikan 'kemudaan' (youthness) di tengah kota besar yang penuh dengan berbagai permasalahan sosial dan ekonomi.

\section{SEKILAS TENTANG MAJ ELIS RASULULLAH}

Majelis Rasululullah didirikan oleh Almarhum Habib Munzir Fu'ad alM usawa. Ia dilahirkan tahun 1973 di Cipanas, Jawa Barat, dan meninggal tgl 15 September 2013 setelah lama mengidap asma dan kanker otak. la adalah anak keempat dari lima bersaudara. Berbeda dengan habib lainnya 
yang orang tuanya berlatar belakang ulama, ayah Habib Munzir berasal dari pendidikan umum. Ayahnya, Fu'ad b. Abdurrahman al-Musawa, memperoleh sarjana S1 jurusan Jurnalisme dari the New York University di Amerika Serikat dan kemudian bekerja sebagai wartawan di Koran Berita Yudha. Habib M unzir menempuh pendidikan SD sampai SM A di Cipanas. Namun, ia berhenti dari sekolah SM A pada saat kelas dua karena sibuk mengelola penginapan ayahnya. Karena keseringan begadang menjaga penginapan, Habib Munzir muda terkena penyakit asma. ${ }^{5}$ Perjumpaan Habib M unzir dengan pengetahuan agama dimulai ketika aktif mengikuti pendidikan di lembaga non-formal majelis taklim dan pesantren. la mulai belajar hukum Islam di Madrasah al-Tsaqafah al-Islamiyyah milik Habib Abdurahman Assegaf di Bukit Duri, Jakarta Selatan. Setelah dua bulan di madrasah tersebut, ia mengikuti kursus Bahasa Arab di LPBA (Pembaga Pendidikan Bahasa Arab) Assalafy yang dikelola oleh Habib Bagir Alatas di Jakarta Timur. Habib M unzir kemudian mendalami pengetahuan agama di Pesantren Al-Khairat milik Habib Hamid Nagib b. Syeikh Abu Bakar di Bekasi Timur. Selama nyantri di tempat inilah ia bertemu dengan ulama terkenal dari Yaman, Habib 'Umar b. Hafiz, yang pada saat itu sedang mengunjugi pesantren tersebut tahun 1994 dalam rangka mencari santri yang akan dikirim ke Hadramawt. Habib Munzir terpilih sebagai salah satu dari 30 santri angkatan pertama yang dikirim. ${ }^{6}$ la menghabiskan empat tahun masa studi di Darul Musthafa, sebuah lembaga pendidikan baru yang didirikan oleh Habib 'Umar. Lembaga pendidikan ini telah memiliki nama besar dan telah menarik banyak mahasiswa dari berbagai Negara, baik dari benua Eropa, Amerika, Afrika, dan Asia.

Setelah menyelesaikan studinya di Yaman, Habib Munzir kembali ke tanah air dan mulai aktivitas dakwahnya tahun 1998. la mengawali dakwahnya di kampung halamannya, Cipanas, namun tidak berkembang seperti yang ia harapkan. la kemudian pindah ke Jakarta mengadakan pengajian yang pindah-pindah dari satu rumah ke rumah lainnya. Awalnya ia hanya mendapati enam jemaah yang setia menyediakan rumahnya untuk pengajian serta tempat untuk istrahat karena saat itu ia pulang pergi dari Cipanas ke Jakarta. Karena sejumlah saran dari jemaahnya, Habib Munzir akhirnya mendirikan majelis taklim yang ia namakan Majelis Rasulullah (MR). Penamaan ini menurutnya karena ajaran dan ceramah yang ia tonjolkan berkaitan dengan pesan-pesan dakwah dari Nabi. Karena jumlah jemaahnya makin membludak, ia akhirnya memindahkan tempat penga- 
jiannya dari rumah-rumah ke masjid besar demi menampung jemaahnya. Masjid ini adalah Masjid Al-M unawwar yang berlokasi di Pasar Minggu, Jakarta Selatan. Ia menetapkan malam senin sebagai jadwal tetap pengajian, mengikuti jadwal gurunya di Hadhramawt.

Habib M unzir sukses mengelola dakwahnya. Ini terbukti dari jemaahnya yang berjumlah ribuan yang kebanyakan dari kalangan muda-mudi. Untuk fokus mengelola majelis taklim, ia menyewa satu rumah di Pancoran sebagai gedung sekretariat atau basis operasi dakwah. la mengangkat beberapa staf dan crew untuk membantu aktivitas dakwahnya. Para stafnya ikut membantu mengatur jadwal pengajian, mengelola media seperti publikasi dan website majelis, dan menjaga gedung sekretariat. la juga mendirikan kios majelis yang menjual merchandises seperti buku, stiker, DVD, jaket seragam majelis, busana muslim dan lain-lainnya. Sebagian staf juga dipekerjakan untuk mengelola kios Islami, Kios Nabawi, termasuk memproduksi dan menjual produk majelis. Jika para staf digaji secara professional sesuai pendapatan yang masuk, para crew bekerja secara sukarela di lapangan ketika majelis akan diadakan, seperti memasang spanduk dan baliho, menggelar tikar, dan mengatur jemaah di lapangan. ${ }^{7}$

\section{KOM POSISI J EM AAH MAJ ELIS RASULULLAH}

Berdasarkan observasi di lapangan, jumlah jemaah di pengajian MR tergantung dari jenis kegiatannya. Pada pengajian rutin seperti malam senin (jalsah itsnain), jumlah peserta sekitar 5.000 sampai 10.000 orang. Namun, di event khusus, seperti perayaan maulid Nabi, jumlah jemaah bisa mencapai $80.000 \mathrm{~s} / \mathrm{d} 100.000$ orang. Karena kapasitas Jemaah yang besar, Habib M unzir berinisiatif mengadakan maulid akbar setiap tahunnya di lapangan Monumen Nasional (M onas). Kebanyakan jemaah M R berasal dari kalangan remaja/muda, berusia sekitar 12-30 tahun. Mereka biasanya memakai jaket hitam M R, kopiah putih, dan sarung (bagi pria), sementara wanita memakai gamis hitam (abaya) dan sebagian memakai cadar.

Secara ekonomi, pengikut M R kebanyakan berasal dari keluarga golongan kelas menengah ke bawah dan golongan miskin. Sebagian besar mereka adalah siswa SLTP dan SLTA yang orang tuanya bekerja dengan penghasilan rendah seperti buruh pabrik, karyawan Mall, sopir angkutan umum (angkot), pedagang kaki lima dan sebagainya. Sebagian jemaah dewasa bekerja dengan penghasilan rendah karena tidak memiliki gelar pendidikan diploma dan sarjana. Sebagian besar jemaah didominasi oleh 
etnis Betawi, namun sebagian lainnya dari etnis Jawa, Sunda, Palembang, dan Banjar. Etnis-etnis ini secara kultural dekat dengan tradisi Islam Nahdlatul Ulama (NU). Etnis Betawi, pada khususnya, tidak bisa dipisahkan dari tradisi Islam seperti maulid, haul, ziarah, dan tahlilan. M uslim Betawi memberikan penghormatan yang sangat tinggi kepada habaib dan kyai. Keterikatan M uslim Betawi dengan Islam tradisi tidak bisa dipisahkan dari peran habaib dan ulama lokal yang menyebarkan Islam sunni (aswaja) sejak abad ke 19 M. ${ }^{8}$ Banyak jemaah M R berasal dari keluarga yang akrab dengan doktrin dan tradisi NU, namun mereka tidak mengecap pelajaran agama di lembaga pendidikan formal, seperti madrasah dan pesantren. Mereka merasa bahwa mengikuti pengajian di MR telah menambah pengetahuan agama, dan ritual-ritual tersebut membuat mereka merasa sebagai Muslim yang shaleh.

Sebagian jemaah mulai ikut di majelis taklim semenjak usia remaja. Mereka pada awalnya penasaran melihat sejumlah baliho besar dan bendera majelis yang tersebar di Jakarta dan sekitarnya. Selain itu, mereka tertarik melihat ragam kegiatan dan merchandise MR yang memikat. Baliho-baliho besar menampilan gambar seorang tokoh bertampang Arab yang dipanggil habib dengan memakai jubah dan surban putih, serta berpenampilan saleh, berwibawa, dan karismatik. Keriuhan dan solidaritas yang diperlihatkan oleh pengikut MR, seperti konvoy sepeda motor dan ajang kopi darat, menjadi salah satu daya tarik bagi kalangan muda. Sebagian jemaah ikut karena diajak kawan dan keluarganya untuk mendalami agama. Walaupun ada berbagai sebab yang mendorong mereka ikut, namun sebagian besar mereka terpesona dengan karisma seorang Habib Munzir. Bagi mereka Habib M unzir adalah sosok penceramah yang ramah dan lembut dalam berdakwah. Mereka merasa bahwa sang habib telah memikat hati mereka sejak pertama kali mengikuti majelis, dan hal ini membuat mereka berkomitmen kepada majelis tersebut. Indri, salah satu jemaah, mengatakan "habibana menggunakan gaya lembut dan gaya sastra dalam berbicara, serta selalu merujuk kepada Nabi Muhammad sebagai model teladan bagi M uslim". ${ }^{9}$

Di majelis habaib, tidak ada aturan keanggotaan yang ketat seperti halnya organisasi Islam. Jemaah bebas mengikuti majelis manapun tanpa ada syarat. Oleh karena itu, tidak heran jika kita melihat ada jemaah berjaket MR yang juga mengikuti Majelis Habib Ali Kwitang atau Majelis Nurul Musthofa. Bagi mereka, semua majelis habib adalah sama dalam hal 
tujuan, tetapi berbeda dalam pendekatan dan strategi. Mereka mencontohkan Habib M unzir dan Habib Rizieq yang sama-sama bertujuan mempertahankan Islam al-sunnah wa al-jama'ah (aswaja), namun strategi keduanya berbeda. Habib yang pertama memakai metode lembut dan damai, tetapi habib yang kedua memakai cara tegas dan konfrontatif. Meskipun ada kesamaan tujuan, para jemaah cenderung berkomitmen pada satu majelis. Komitmen ini diekspresikan melalui partisipasi rutin dalam satu majelis dan jaket seragam yang dikenakan. Berbeda halnya dengan anggota biasa, para staf dan crew M R memiliki peran khusus dan fokus bekerja untuk keberlangsungan kegiatan. Selain mengadakan acara keagamaan, para staf dan crew juga bertugas mengumpulkan dana melalui berbagai program dan penjualan produk MR. Dana besar biasanya dibutuhkan ketika mengadakan perayaan besar M aulid Nabi SAW setiap tahun di lapangan Monas, Jakarta Pusat.

\section{J AKARTA, KAUM MUDA URBAN, DAN KESENANGAN}

\section{Aspirasi Kesalehan dan Kesenangan}

Untuk memahami popularitas habaib di kalangan anak muda di Jakarta dan kota lainnya, kita mesti menganalisa hubungan antara lahan kota (urban space) dan masalah sosial anak muda. Jakarta adalah ibu kota negara dan kota terbesar dengan jumlah penduduk terpadat di Indonesia. Sebagai pusat pemerintahan dan bisnis, Jakarta menjadi destinasi utama bagi mereka yang tinggal di daerah dan pedalaman, untuk memperoleh kesuksesan materi dan popularitas. M eningkatnya urbanisasi telah membuat kota tersebut menjadi kota terpadat di Asia Tenggara. Pada tahun 2014, jumlah penduduknya mencapai hampir 10 juta jiwa. ${ }^{10}$ Adanya kesenjangan antara para pencari kerja terdidik dan pekerjaan yang tersedia memicu persaingan di antara penduduk kota. Berbagai masalah bermunculan, seperti kesenjangan ekonomi, pengangguran, perumahan yang tidak layak, dan kondisi transportasi dan lingkungan yang buruk. ${ }^{11}$ Bappeda DKI Jakarta melaporkan bahwa tingkat kemiskinan telah meningkat dari 312.200 jiwa pada tahun 2010 ke 412,790 pada tahun 2014. ${ }^{12}$ Belum lagi pembangunan ekonomi yang meningkat selama beberapa dekade, seperti pembangunan pusat pertokoan, mall, dan pemukiman elit, menyebabkan terjadinya penggusuran kampung-kampung di mana rakyat kecil menjadi korban. Akibat dari semua ini, Jakarta menjadi terlampau padat, macet, dan juga menimbulkan kesulitan ekonomi dan 
stress di kalangan penduduk kota.

Berbagai problem kota di atas berdampak pada anak-anak muda kota, khususnya yang berasal dari keluarga kelas menengah ke bawah. Mereka ini berada dalam fase transisi dari masa remaja ke masa dewasa. Anak muda Indonesia memiliki sifat unik. M ereka sangat suka bersosialisasi dan menyukai suasana yang ramai, di tempat di mana mereka dapat berinteraksi dengan sesamanya dan mencari pengalaman baru yang seru dan mengasyikkan. ${ }^{13}$ Namun demikian, Jakarta, karena keterbatasan lahan, hanya menyediakan tempat yang terbatas bagi anak muda untuk bersosialisasi dan mengekspresikan diri. M enurut Atmodiwirjo, para remaja di Jakarta sangat jarang menggunakan pusat kegiatan remaja yang disediakan oleh pemerintah sebab tidak terawat dan terlihat kurang menarik. Mereka lebih suka menghabiskan waktu di pusat perbelanjaan (mall) dan di area fasilitas publik seperti halte bus, terminal, lahan parkir, halaman sekolah, sudut-sudut jalanan dan jembatan. Nongkrong di tempat tersebut memungkinkan mereka untuk menghibur diri dan lebih bebas dari pantauan orang tua. ${ }^{14}$ Karena faktor ekonomi, anak-anak muda ini juga tidak mampu menikmati waktu senggang di tempat-tempat yang berbayar, tidak mampu membeli pakaian mahal, dan juga tidak mampu menikmati hobi olahraga dan kesenian yang membutuhkan biaya.

Banyak jemaah anak muda, dari keluarga berpenghasilan rendah, yang akhirnya menemukan aktivitas keagamaan sebagai saluran untuk berekspresi dan menunjukkan eksistensi mereka. Jika sebagian gerakan Islam cenderung menekan kesenangan dan melarang hiburan yang terkait dengan budaya Barat, gerakan dakwah habaib cenderung lunak dan mengakomodasi aspirasi anak muda dengan menggabungkan budaya pop dan ajaran Islam. Ketika berbincang dengan jemaah beberapa majelis habaib di Jakarta, sebagian mereka memuji habib-nya yang dianggapnya 'keren' dan 'gaul'. Disebut keren karena sang habib memiliki potongan jenggot yang menarik khas anak muda, memakai kostum yang berwarna terang, sorban yang unik, kacamata hitam, dan ornamen lainnya yang menarik; sementara disebut gaul karena ia memakai aksen Jakarta ala sinetron yang akrab di telinga anak remaja kota. Banyak jemaah muda yang tempat tinggalnya jauh dari lokasi pengajian dan seringkali memakan waktu sampai larut malam. Mereka ini leluasa keluar malam dan mendapatkan izin dari orang tuanya dengan alasan mengikuti pengajian. Narasi partisipasi mereka di pengajian habib beragam. Sebagian terdorong 
ikut karena alasan keagamaan, namun sebagian didorong oleh tujuan memperoleh kesenangan dan pergaulan sosial dari kegiatan majelis. Ketika di lapangan, penulis agak kaget melihat jemaah remaja (putra dan putri) yang mengikuti pengajian sampai larut malam (jam 22.00-23.00). Dilihat dari padatnya lalu lintas setelah kegiatan majelis dan jarak rumah mereka, maka kemungkinan ada jemaah yang tiba di rumah mereka sekitar jam 12 atau jam 1 malam. Mereka mengatakan bahwa orang tua mereka sangat mendukung kegiatan ini, meskipun keluar malam, karena tujuannya untuk mendalami agama (ta'lim). Orang tua mereka berharap bahwa dengan pengajian tersebut dapat membawa peningkatan moral dan spiritual sang anak. Sikap seperti ini umum di kalangan orang tua M uslim di Indonesia. M enurut Parker dan Nilan, sikap seperti ini merupakan respon terhadap diskursus 'kepanikan moral' (moral panic) yang telah menyebar di kalangan orang tua, media, dan Negara. ${ }^{15}$ Oleh karena itu, partisipasi dalam kegiatan agama dan konsumsi Islami mendapat dukungan dalam rangka melindungi anak muda-mudi dari pengaruh negatif, seperti kenakalan remaja dan konsumsi obat-obat terlarang.

Keaktifan anak muda di majelis pengajian telah menjadi wahana bagi mereka untuk menghabiskan masa muda secara menyenangkan, namun bersifat religius. Mereka melihat majelis taklim sebagai tempat untuk mempelajari Islam dan sekaligus tempat untuk menikmati 'kesenangan' dengan kawan sebaya mereka. Mereka menikmati kesenangan yang ditujukan untuk kepentingan agama. Para anak muda memanfaatkan majelis sebagai medan untuk bersosialisasi atau bergaul, menunjukkan eksistensi, dan menjalani mobilitas sosial. Dalam lingkungan seperti ini, para anak muda memiliki kesempatan untuk memperoleh teman, dukungan emosional, dan pengalaman baru. ${ }^{16}$

\section{Mencari B erkah Sang Habib}

Berbagai permasalahan di kota besar juga membuat anak-anak muda mencari naungan spiritual dan berkah orang suci (wali). Ini terjadi khususnya pada anak muda dari kalangan kelas menengah kecil ke bawah, baik yang lama di Jakarta ataupun pendatang baru (newly urbanized) yang sedang mencari kesejahteraan ekonomi dan kehidupan yang lebih baik. Sebagian dari pengikut majelis habib adalah mahasiswa, sebagian pengangguran, dan sebagian adalah buruh atau karyawan rendahan yang bekerja di pertokoan, mall, dan di pabrik. Kota besar adalah magnet bagi 
penduduk Indonesia yang ingin mencari pekerjaan yang layak dan prestisius. Namun, tinggal di kota besar tidaklah langsung menjamin pencapaian kesejahteraan dan masa depan yang lebih baik kepada penghuninya. Banyak anak muda yang menganggur atau, paling tidak, memperoleh pekerjaan yang bergaji rendah. M enurut Ben White, angka pengangguran di Indonesia cukup tinggi dan hal ini mengikuti trend perkembangan global dimana pendidikan tinggi tidak menjamin akses ke pekerjaan yang stabil. Hal ini disebabkan oleh ketidakseimbangan antara lahan kerja dengan jumlah alumni SLTA dan universitas yang meningkat setiap tahunnya. Kelangkaan lahan kerja formal akhirnya mengarahkan mereka bekerja di sektor-sektor informal meskipun dengan upah rendah. ${ }^{17}$ Dengan kondisi tersebut, penghasilan kaum muda hanya cukup menghidupi kebutuhan sehari-hari untuk dirinya dan keluarganya tanpa ada sisa untuk simpanan atau investasi. Kondisi ini menciptakan kecemasan dan ketidakpastian bagi anak muda yang menghadapi kerasnya kehidupan Jakarta. Hal ini membuat mereka mencari naungan spiritual atau intervensi Tuhan dalam rangka memperoleh ketenangan hidup, solusi instant, dan keajaiban untuk memecahkan berbagai masalah duniawi.

Para pengikut majelis memandang partisipasi di pengajian dan kedekatan dengan habaib mampu mengalirkan keberkahan (barakah). Konsep berkah sangat krusial bagi M uslim tradisional. Ini terkait dengan pimpinan majelis yang memiliki ikatan darah dengan Rasulullah. Dalam bahasa Arab, barakah berarti 'perkenan ilahi'. Kata ini juga berarti kebajikan yang mendatangkan kelimpahan rezeki, kesejahteraan, dan kebahagiaan. ${ }^{18}$ M enurut Liyakat Takim, berkah juga diasosiasikan dengan "kesejahteraan, keberuntungan, kelimpahan, dan kekuatan yang luar biasa." ${ }^{19}$ Berkah dipercaya dapat ditemukan pada waktu dan tempat tertentu, atau pada orang suci. Orang-orang suci seperti habib, sufi, dan wali dipercaya memiliki keberkahan. Berkah bukan hanya pada wali yang hidup dan objek suci, tetapi juga pada wali yang sudah meninggal. ${ }^{20} \mathrm{Habaib}$, khususnya, mewarisi berkah dari Nabi melalui ikatan darah. Bahkan setelah mereka meninggal, kuburan mereka dimuliakan karena ketinggian spiritualitas, keilmuan, dan pencapaian di masa hidupnya. ${ }^{21}$

Anak-anak muda yang ditimpa ketidakpastian dan kecemasan hidup berharap dengan partisipasinya di majelis taklim dapat membuahkan keberkahan dan kesejahteraan buat mereka. Dengan hal tersebut, segala problema hidup mereka dapat dipecahkan. M ereka percaya bahwa melihat 
langsung wajah habib dan mencium tangannya mampu mentransmisikan berkah Nabi buat mereka. Ketika di lapangan, penulis bertemu dengan beberapa jemaah yang bekerja sebagai buruh di mall, toko, dan pabrik. Mereka mengatakan meskipun sangat sibuk dalam bekerja dan rumah mereka jauh dari area pengajian, mereka mengupayakan untuk rutin mengikuti pengajian M ajelis Rasulullah paling tidak sekali dalam seminggu, dengan harapan mereka dapat meraih berkah. Berkah ini diharapkan mampu membawa perbaikan bagi kehidupan ekonomi dan masa depan kerja mereka yang lebih baik.

\section{Majelis sebagai Sarana Ekspresi Anak Muda}

Para habaib muda di Jakarta berupaya menarik jamaah dengan menggunakan berbagai strategi kreatif. Strategi yang paling utama adalah menggunakan baliho, spanduk, poster, dan media sosial. Sebagian jemaah tertarik mengikuti majelis setelah melihat informasi pengajian di spanduk pinggir jalan dan poster pengumuman di website dan media sosial. Website majelis dan halaman komunitas (community page) di media sosial, khususnya Facebook, biasanya mengumumkan dan menyebarkan jadwal kegiatan untuk empat minggu berikutnya. Penggunaan internet, terutama media sosial, bagi sarana dakwah sangat strategis di Indonesia. M enurut data Kementerian Komunikasi dan Informasi, pengguna internet di Indonesia telah mencapai 63 juta pada tahun 2013. Dari jumlah ini, ada 95\% menggunakan internet untuk mengakses media sosial. Dalam hal pemakaian Facebook, misalnya, Indonesia berada pada posisi keempat di dunia setelah Amerika, Brazil, dan India. ${ }^{22}$ Isparmo Seo juga melaporkan bahwa kebanyakan pengguna Facebook adalah anak muda dengan usia antara 18-34 tahun. Dengan popularitas smart-phone saat ini, anak-anak muda sering menggunakan waktu senggang mereka untuk berkomunikasi lewat layanan online seperti BBM (BlackBerry M essenger), WhatsApp, Line, serta posting status dan mengomentari status kawannya di media Sosial. ${ }^{23}$

Kebanyakan pengikut majelis habaib akrab dengan media sosial. M ereka memakai media sosial untuk mengikuti perkembangan program majelis dan menjaga komunikasi dan solidaritas dengan kawan seperjuangan. Banyak grup/komunitas pecinta majelis, baik yang resmi dan tidak resmi, yang tersedia di media sosial. Dengan mengamati percakapan di grupgrup tersebut, saya dapat melihat begitu pentingnya peranan website majelis dan media sosial bagi pengikutnya. Melalui medium tersebut, 
mereka dapat mengikuti jadwal terkini majelis, menonton program dakwah yang sebelumnya ataupun yang lagi live, dan mengunduh berbagai lagu shalawat dan tausiyah dari sejumlah penceramah. Selain itu, di website juga ada bagian untuk tanya-jawab agama, diskusi, dan sharing informasi di kalangan jemaah.

Media sosial juga penting untuk mempromosikan berbagai produk majelis dan menggalang dana dengan berbagai program. Berikut adalah contoh posting majelis di halaman komunitas FB:

"A ssalamu A laikum jemaah M ajelis Rasulullah.

D iharapkan untuk membeli produk asli dari M ajelis Rasulullah. K arena membeli produk tersebut berarti anda membantu perjuangan dakwah $\mathrm{N}$ abi di Jakarta. $M$ ari kita wujudkan cita-cita guru kita, A Imarhum $\mathrm{H}$ abib M unzir A I-M usawa. Bagi jemaah yang mau membeli DV D pemakaman $\mathrm{H}$ abib $M$ unzir, anda dapat membelinya di Kios $\mathrm{N}$ abawi malam ini di M ajid A I-M unawar, Pancoran. K ami berharap anda tidak membeli DVD di tempat lain, kecuali di Kios $\mathrm{N}$ abawi. Jazakallahu K hair." ${ }^{24}$

Selain mengakses media majelis, para jemaah muda juga menggunakaan asesoris majelis, khususnya jaket $M \mathrm{R}$, sebagai simbol kesalehan dan identitas kelompok. Anak-anak muda ini bangga memakai jaket M R yang menunjukkan afiliasi mereka ke majelis habib. Jaket tersebut menyimbolkan pula bahwa mereka adalah Muslim saleh yang berafiliasi ke kelompok Islam tradisional, atau yang popular disebut Islam aswaja. Penggunaan simbol-simbol majelis seperti ini memperkuat apa yang diistilahkan oleh Durkheim sebagai 'representasi sosial' dari agama. ${ }^{25} \mathrm{Habib}$ Munzir berinisiatif menggunakan jaket majelis dan merchandise lainnya sebagai sarana untuk syiar agama di kalangan anak muda. Kesuksesan Habib Munzir kemudian menginspirasi munculnya sejumlah habib yang menggunakan metode yang sama. Menurut Mara Einstein, seseorang yang mengonsumsi produk agama tertentu berarti ia mendefinisikan identitas personalnya sebagai konsumer. Lanjutnya lagi, "sang penjual lah (marketer) yang memberikan makna pada produk, dan makna inilah yang dikonsumsi oleh pembeli." 26 Terkait dengan teori ini, merek MR (yang mengangkat Nabi sebagai simbol dakwah) menunjukkan bahwa habaib membingkai ajaran dan praktek agama mereka murni berasal dari Nabi. Keterkaitan dakwah MR dengan Nabi diperkuat pula oleh para habaib yang memiliki ikatan darah dengan Nabi.

Majelis-majelis habaib di kota besar menyediakan wadah buat anak 
muda untuk mengekspresikan "kemudaannya" (youthfulness). Konsep kemudaan di sini bukan hanya bermakna tahapan usia, tetapi juga momentum dan ragam aktivitas untuk mengekspresikan identitas dan menikmati kesenangan yang biasanya dijalani oleh kaum muda. Di masa lalu, majelis taklim pada umumnya dihadiri oleh jemaah orang tua dan separuh baya. la lebih populer, khususnya, pada kalangan ibu-ibu rumah tangga di perkotaan. Pengajian biasanya di adakan secara rutin dan diadakan di M asjid, rumah-rumah jemaah, atau di satu ruangan permanen milik sang penceramah. ${ }^{27} \mathrm{Hal}$ ini sangat berbeda dengan model pengajian ala habaib muda belakangan ini yang jemaahnya didominasi oleh anak muda. Ini juga berbeda dengan gerakan Islam global yang bergairah menyasar anak muda di sekolah-sekolah dan kampus-kampus. Jika gerakan-gerakan tersebut mempunyai program rekrutmen dan kaderisasi bagi anggota baru, majelis habaib lebih terbuka ke publik dan tidak membutuhkan keanggotaan resmi. Namun demikian, habaib dan stafnya biasanya meminta jemaah untuk komitmen pada majelis mereka agar lebih dalam mempelajari ajaran Islam dan ikut andil memperjuangkan "dakwah Nabi". Dari interaksi penulis dengan para crew dan jemaah, nampaknya program-program majelis menjadi wahana bagi mereka untuk, apa yang disebut Bayat sebagai, "mengklaim dan mengklaim kembali kemudaan mereka (youthfulness)" ${ }^{28}$ Bayat memaknai 'youthfullness' sebagai "sebuah habitus dan disposisi kognitif dan perilaku yang terkait dengan kenyataan untuk menjadi anak muda, yaitu lokasi sosial antara masa kanak-kanak dan masa dewasa, dimana mereka mengalami otonomi relatif, tidak bergantung kepada orang dewasa, namun tidak independen, dan mereka bebas dari tanggung jawab".29

Penulis bertemu dengan beberapa crew majelis yang sangat bangga menjadi bagian dari Majelis Rasulullah. Crew adalah istilah bagi jemaah majelis yang secara rutin bertugas sebagai "event organisers" untuk kesuksesan acara. M ereka biasanya memakai jaket hitam M R dan di depan jaket mereka tertulis 'CREW' atau 'AKTIVIS'. Mereka ini biasanya sangat sibuk menyediakan berbagai hal untuk acara pengajian seperti menangani urusan pemasangan spanduk, panggung, audio system, karpet, dan mengatur lalu lintas jemaah yang padat. Salah seorang yang saya temui mengatakan bahwa tidaklah gampang menjadi crew seperti dirinya, karena harus mengikuti pengajian rutin khusus di sekretariat majelis dan mereka. Mereka biasanya mengenakan jaket MR dipadukan dengan sarung dan 
peci putih, sebuah tampilan yang umumnya diasosiasikan dengan M uslim traditionalis di pedesaan. M ereka bekerja secara sukarela dalam mempersiapkan segala hal untuk kelancaran kegiatan, termasuk penggalangan dana (fund-raising). Seorang crew majelis, Syaiful Anwar, menyatakan kepada penulis bahwa ia dipercayakan sebagai kordinator ziarah (makam keramat) untuk cabang Cidodol, Jakarta Selatan. Ziarah adalah salah satu di antara sejumlah program MR yang diadakan setiap minggu. Meski mengaku ia tidak menerima upah sama sekali, namun Syaiful merasa sangat bangga dengan posisinya sebagai kordinator ziarah. ${ }^{30}$

Aktivisme, mobilitas, dan kesenangan adalah beberapa unsur dari ekspresi anak muda. Di majelis, anak-anak muda dapat bertemu dengan kawan sebayanya dan bersama-sama menyalurkan aspirasi dan bertukar pengalaman. Komitmen perjuangan pada majelis membuat mereka aktif dan mobile karena majelisnya diadakan di berbagai tempat. Mereka aktif membangun jaringan komunikasi dengan dengan sesama pengikut dan staf MR. Dalam hal ini, banyak pengikut, baik itu crew maupun jemaah biasa, menciptakan grup-grup online melalui HP, seperti di BBM dan WhatsApp (WA). Selama riset, penulis bergabung dalam grup-grup online tersebut dan mampu mengikuti dan memantau percakapan informal dan diskusi yang berkembang di kalangan pengikut MR. Di grup WhatsApp, misalnya, para anggota aktif berkoordinasi dan sharing informasi tentang berbagai isu yang terkait dengan majelis. Sebagian informasi dan percakapan bersifat serius, namun mereka lebih sering bercanda dan saling share cerita dan gambar meme lucu untuk menghibur sesama kawannya. Atmosfir di grupgrup online ini sifatnya santai dan para anggota bisa melucu dan saling meledek satu sama lain untuk mengakrabkan diri dengan anggota lainnya.

Pergaulan sosial dengan para crew dan jemaah lainnya adalah ciri lain dari ekspresi anak muda. Program-program rutin majelis menjadi sarana untuk sosiabilitas dan ekspresi sosial. Banyak pengikut majelis yang berinteraksi secara online tanpa pernah bertemu satu sama lain. Untuk memperkuat hubungan dan komitmen di antara jemaah, khususnya para jemaah online, para staf M R juga mengadakan pertemuan informal yang diistilahkan dengan 'Kopi Darat', disingkat menjadi Kopdar. Istilah ini mengikuti tren anak muda yang menindaklanjuti pertemanan dunia maya ke dunia nyata. Kegiatan Kopdar biasanya diadakan di rumah salah satu Jemaah yang berminat. Kegiatannya mencakup kata sambutan dari tuan rumah dan staf MR, pembacaan teks maulid diiringi musik hadhrah, 
ceramah singkat, doa, dan ditutup dengan makan siang bersama. Sesi pra-acara dan makan siang nampaknya menjadi wahana bagi para peserta untuk saling berkenalan dan menceritakan pengalaman hidup masingmasing sebagai jemaah MR.

Partisipasi di majelis taklim tidak berarti bahwa para anak muda menolak hubungan asmara dan kesenangan di waktu luang. Berbeda dengan kelompok dakwah lainnya yang membatasi secara ketat interaksi pria dan perempuan, interaksi antara pengikut majelis habaib yang saya amati nampak cair, meskipun sebagian jemaah wanita memakai cadar. M emang selama pengajian ada garis pembatas yang memisahkan jemaah pria dan wanita, tapi sebagian tidak peduli dan mengambil posisi duduk bersebelahan dengan pasangan mereka (suami/isteri atau pacar) selama pengajian. Sebelum dan sesudah majelis nampak sebagian jamaah anak muda (kebanyakan remaja) berboncengan dengan pasangan mereka yang juga aktif di majelis.

\section{H abaib sebagai Wali dan Teladan Moral}

Popularitas Majelis Rasulullah di kalangan anak muda tidak bisa dilepaskan dari peranan pimpinananya, almarhum Habib Munzir bin Fu'ad alMusawa. Kebanyakan wawancara dan percakapan para jemaah menunjukkan kalau Habib Munzir dianggap sebagai ulama karismatik yang ceramah dan karakternya memberikan kesan mendalam bagi pengikutnya. Banyak pengikut yang terpesona dengan kepribadian Habib Munzir yang, menurut mereka, mencerminkan kepribadian Rasulullah SAW. Salah satu jemaah, Puput, menceritakan bahwa ia pertama kali tertarik dengan M R karena penasaran melihat spanduk-spanduk $M R$ yang terpasang di beberapa sudut kota Jakarta. la penasaran melihat gambar seorang habib yang nampak saleh, berilmu, dan karismatik. Berkat ajakan dari kawan-kawannya di SMA, ia mengikuti maulid akbar di lapangan Monas. Setelah melihat langsung sosok habib Munzir dan mendengarkan ceramahnya, ia merasakan adanya pesona dari sang habib. Puput mengatakan:

“Tak pernah saya jumpai sosok yang lemah lembut seperti sosok yang berdiri di atas panggung waktu itu. Tak pernah saya jumpai sosok yang ketika memandangnya menambah mahabbah (kecintaan) saya kepada Allah dan Rasul-Nya. Tak pernah pula saya jumpai seorang da'i yang ketika ia berbicara seakan-akan beliau bukan berbicara kepada jutaan orang yang hadir, tapi seakan-akan ia berbicara hanya pada diri saya. Beliau seakan- 
akan tahu setiap masalah yang menerpa saya." 31

Seorang staf MR juga menggambarkan kesannya terhadap karakter Habib M unzir ketika mereka bekerja bersama di sekretariat MR:

“H abib M unzir memiliki sifat mulia yang mirip dengan $\mathrm{N}$ abi dari berbagai sisi.

Jika salah satu muridnya melakukan kesalahan, habib hanya tersenyum, memaafkan dan mendoakannya agar ia tidak mengulanginya lagi. la punya cinta yang sangat besar kepada $\mathrm{N}$ abi M uhammad dan juga gurunya, $\mathrm{H}$ abib $\mathrm{U}$ mar bin $\mathrm{H}$ afiz. Karena besarnya kecintaan beliau kepada $\mathrm{Nabi,} \mathrm{Allah}$ memanggilnya agar ia bisa bertemu dengan kekasihnya. D ulu, saya pernah bikin salah dan membuatnya marah, namun beberapa menit kemudian beliau minta maaf karena kemarahannya. B eliau sering minta maaf kepada jemaah ketika membatalkan acara karena sakit yang dialaminya." 32

Karisma Habib M unzir dikembangkan dan disebarkan lewat media MR dan penerbitan habaib. Silsilahnya sebagai keturunan Nabi dan keahliannya dalam ilmu-ilmu agama menjadi 'modal religius' (meminjam istilah Bourdieu) bagi Habib Munzir. Modal religius dalam istilah Bourdieu merujuk kepada qualifikasi agama atau 'akumulasi buruh simbolik' yang mana para ahli agama mampu memonopoli kekuatan agama yang legitimate bagi orang awam dan pengelolaan produk dan layanan agama. ${ }^{33}$ Namun demikian, Habib M unzir tidak akan memperoleh popularitas yang cepat dan modal religious tanpa memanfaatkan strategi marketing dan teknologi media. Melalu berbagai media, Habib Munzir dipromosikan sebagai penceramah baru yang otoritatif, keturunan Nabi, dan juga wali yang memiliki karamah. Biografi dan foto-fotonya bukan hanya ditampilkan di sejumlah majalah, seperti al-Kisah dan Cahaya Nabawi, namun juga di media sosial. Walaupun ayahnya bukan ulama, latar belakang pendidikannya di Hadhramaut di bawah asuhan Habib Umar, menambah daya jual dan otoritasnya di mata umat. Otoritasnya makin kuat ketika gurunya dari Yaman sering datang mengisi pengajian dan zikir M R setiap tahunnya.

Iklan media dan produk keagamaan M R sesuai dengan ekspektasi anak muda M uslim yang lagi mencari tokoh religius dan panutan moral. M ereka melihat bahwa Habib Munzir menyediakan ajaran Islam dan naungan spiritual. Meskipun banyak jemaah yang bertujuan memperdalam pendidikan agama, namun mereka juga mengakui bahwa mereka memperoleh perasaan tenang dan damai serta bebannya sedikit berkurang setelah mengikuti pengajian MR. Salah satu jemaah mengatakan kepada penulis:

"H al yang membuat saya tertarik dengan $\mathrm{M}$ ajelis Rasulullah adalah perasaan 
tenang dan damai ketika menghadiri majelis. Saya tidak pernah merasakan ketenangan seperti itu di majelis lainnya. Bagi saya, M ajelis Rasulullah penuh dengan kedamaian dan ketenangan ditambah dengan nasehat-nasehat agama dan pembacaan salawat $\mathrm{N}$ abi." ${ }^{34}$

\section{Memperjuangkan Jakarta sebagai K ota Nabawi}

Keikutsertaan anak muda di pengajian Majelis Rasulullah bukan sekedar aktivitas pasif, namun mereka ikut membantu memperjuangkan misi dakwah Habib M unzir. Dalam berbagai program, Habib Munzir mengajak pengikutnya untuk mengubah Jakarta menjadi 'Kota Nabawi'. Istilah ini bermakna bahwa Habib Munzir berupaya membawa nilai-nilai Islam, sesuai yang diajarkan dan dicontohkan oleh Nabi, di Jakarta. Menurut tim M R dalam bukunya:

“Intinya, dakwah Habib Munzir bertujuan memperkenalkan karakter Nabi Muhammad di kalangan masyarakat Jakarta dan kota lainnya yang terlalu sibuk dengan kehidupan duniawi. Dengan dakwah ini diharapkan munculnya gairah untuk mencintai dan membela sunnah-sunnah Nabi. Lambat laun tapi pasti, mereka akan menjadi laskar Allah, bukan laskar yang menyebarkan ajaran Nabi lewat jalur kekerasan, tetapi lewat teladan akhlak yang dicontohkan oleh Nabi." ${ }^{35}$

Misi dakwah Habib M unzir sangat terkait dengan ajaran dakwah yang didapatkan dari gurunya di Yaman, yaitu Habib Umar. Salah satu ciri utama dari dakwah Habib Umar adalah penghormatan yang tinggi kepada Nabi Muhammad dan keturunannnya dengan cara melestarikan tradisi lama para habaib yang sempat dilarang oleh pemerintah Yaman di era rejim sosialis. ${ }^{36}$ Habib Umar mendirikan lembaga pendidikan tradisional, Darul Mustafa, yang punya perhatian besar pada dakwah. Beberapa habib yang pernah berguru ke Habib Umar menyatakan bahwa selama nyantri di Darul M ustafa, mereka seringkali dikirim untuk berdakwah ke beberapa desa di Yaman. Setelah mereka selesai dari sekolah, para alumni juga diharapkan aktif untuk menyebarkan dakwah melalui berbagai medium, baik melalui lembaga pendidikan, ceramah, atau media. Habib Umar seringkali mengadakan perjalanan keliling dunia, khususnya di Asia Tenggara, untuk memantau perkembangan dakwah para muridnya.

Kesuksesan Habib Munzir dalam berdakwah bisa difahami dari kemampuannya untuk memobilisasi anak-anak muda untuk membantu dan mendukung misi dakwahnya. Dengan slogan "mengubah Jakarta 
menjadi kota Nabawi", Habib Munzir mengajak para anak muda untuk bergabung sebagai staf dan crew Majelis Rasulullah. Para staf majelis menerima pengajaran khusus di sekretariat M R secara rutin dan memperoleh upah dari pekerjaannya. Pendidikan agama berkesinambungan yang diperoleh dari Habib Munzir membuat mereka istiqamah dan berdedikasi untuk membantu perjuangan dakwah sang Habib. Keakraban dan penghormatan kepada Habib M unzir bisa dilihat dari panggilan 'habibana' (habib kami) atau 'guru kita' yang disematkan pada gurunya tersebut.

Para pengikut MR, baik staf ataupun crew, berperan sebagai event organizer dan produsen produk keagamaan. Mereka mensyiarkan dakwah M R lewat strategi marketing dan merchandising. M enurut mereka, produkproduk MR seperti buku agama, baju Muslim/Muslimah, jaket, dan berbagai asesoris Islam adalah sarana untuk memperkenalkan ajaran Nabi. Di samping itu, keuntungan dari produk ini digunakan untuk mendukung dakwah MR sekaligus pemberdayaan ekonomi bagi jemaah MR. Selain merchandise, para pengikut M R juga aktif mengadakan program kegiatan yang bertujuan menggalang dana buat pengajian akbar di masa mendatang, khususnya kegiatan tahunan M aulid Nabi yang membutuhkan biaya besar. Mereka, misalnya, mendorong sejumlah grup-gurup informal di bawah MR untuk berlomba-lomba mengumpulkan dana. Grup-grup tersebut antara lain: grup ziarah, grup kopdar, grup milis M R, grup helm MR (buat pengendara motor), dan grup lainnya. Ada pula sejumlah grup atau komunitas yang berdasarkan daerah seperti MR Bekasi, MR Depok, M R Cijantung, MR Cibubur, M R Cilincing, dst. Setiap grup memobilisasi anggotanya dalam pencarian dana dan saling berkompetisi dengan grup lainnya. Salah satu contoh penggalangan dana adalah lewat kegiatan program ziarah di Jakarta dan Cipanas yang berlangsung tgl 12 Januari 2014. Di mailing list M R diumumkan bahwa kegiatan tersebut, ditambah dengan kegiatan 'Kopi Darat', telah berhasil mengumpulkan dana sekitar 20 juta rupiah.

Dalam pandangan para pengikut M R, istiqamah pada M ajelis Rasulullah bermakna sebagai pengabdian dan perjuangan untuk melanjutkan misi Nabi. Habib M unzir dan stafnya membingkai kegiatan keagamaan mereka sebagai jalan untuk menyenangkan Nabi atau membuat Nabi bahagia. Kegiatan tersebut, misalnya, dalam bentuk pembacaan kitab maulid yang berisi kisah dan pujian terhadap Nabi. Penekanan pada Dakwah Nabi nampaknya menarik para anak muda di ibu kota. Dengan bergabung di 
M R, para pengikut merasa sedang melanjutkan perjuangan dakwah Nabi. Aktivisme ini menyediakan makna (meaning) bagi anak muda dalam mengarungi kehidupan dunia mereka. Bagi mereka, partisipasi tersebut akan membuahkan keberkahan dalam hidup dan pertolongan syafa'at di akhirat. Apalagi mengingat pimpinan majelis adalah keturunan $\mathrm{Nabi}$ yang berarti mampu mentransmisikan keberkahan dari Nabi. Keberkahan ini diharapkan mampu mengatasi berbagai kesulitan hidup yang mereka alami seperti masalah kesehatan, masalah keluarga, masalah ekonomi, masalah ujian sekolah dan masalah lainnya.

\section{KESIM PULAN}

Artikel ini telah menganalisis pandangan dan pengalaman para pengikut Habib Munzir di Jakarta. Hal ini adalah upaya untuk memahami menaiknya pengaruh dan popularitas habaib muda di kalangan anak muda di kota-kota besar. Penulis telah menunjukkan bahwa partisipasi anak muda di majelis taklim bukan hanya sebagai daya tarik sufisme atau revivalisme spiritual, seperti yang ditunjukkan oleh beberapa peneliti. Penulis berargumen bahwa anak muda M uslim melihat M R bukan hanya sebagai wadah untuk mengekspresikan kesalehan, namun juga mengekspresikan 'kemudaan' mereka. Daya tarik M R kepada anak muda tidak dapat dipisahkan dari strategi sang habib yang memodifikasi secara kreatif dakwahnya melalui berbagai medium yang sesuai dengan kebutuhan dan aspirasi para anak muda kota. Medium tersebut mencakup penggunaan media baru (internet dan media sosial), logo, simbol, merchandising, panggung pertunjukan, dan pendirian komunitas-komunitas pengikut. Para pengikut bukan hanya berpartisipasi untuk belajar agama, namun juga menikmati 'kesenangan' lewat interaksi sosial dengan rekan-rekan seperjuangan mereka di majelis. Oleh karena itu, studi ini memperkuat peran media baru dan budaya populer sebagai sarana untuk menarik anak muda ke agama. Pada titik ini, Islam tradisional, yang biasanya diasosiasikan dengan domain pedesaan, bisa tampil modern dan stylish sehingga memikat kalangan muda di perkotaan.

Studi ini juga menunjukkan bahwa faktor tokoh tetap penting untuk menarik para pengikut. Hal ini beresonansi dengan popularitas para penceramah selebritis di Indonesia yang mengandalkan kemampuan public speaking yang dimilikinya. Namun demikian, Habib Munzir memiliki kelebihan khusus, yaitu ia mengkombinasikan aspek silsilah (sayyid) dan 
kearaban, latar studi di Yaman (murid Habib Umar), dan popularisasi 'Dakwah Nabawi'. Beberapa elemen ini menjadi modal kultural bagi Habib Munzir dan memperkuat otoritasnya di kalangan pengikutnya. Para anak muda melihat Habib Munzir sebagai wali dan tokoh kharismatik, ulama otoritatif, dan teladan akhlak Nabi yang darinya mereka mengambil pelajaran, idola, dan berkah. Kebanyakan dari pengikut dan jamaah MR berasal dari kalangan ekonomi kelas bawah yang telah terpinggirkan oleh massifnya pembangunan kota, ketidakadilan ekonomi, dan mis-manajemen kota. Anak-anak muda ini merasakan ketidakpastian dan ketidakamanan dalam hal masa depan mereka. Dengan ikut serta dalam majelis habaib dengan berbagai programnya, mereka menemukan ketenangan batin, identitas kesalehan, dan harapan lewat doa-doa dan berkah habaib yang membuat mereka lebih kuat dan optimis dalam menjalani hidup dan menyongsong masa depan.

\section{CATATAN AKHIR}

1 Penulisadalah dosen Fakultas I Imu Dakwah \& IImu Komunikasi, U IN Syarif $\mathrm{H}$ idayatullah Jakarta. I a menyelesaikan studi doktoral di jurusan Perubahan Sosial \& Politik di Australian National U niversity (ANU ), C an berra, Australia.

2 Lihat misalnya Rifki Rosyad, A Q uest for True Islam: A Study of the Islamic Resurgence $M$ ovement among the Youth in Bandung, Indonesia (C anberra: ANU E-Press, 1995); Salman, "The Tarbiyah M ovement: Why People Join This Indonesian Contemporary Islamic M ovement". Studia Islamika, Vol. 13, No. 2, (2006), hIm171-241; N oorhaidi H asan, Laskar Jihad: Islam, M ilitancy, and the $Q$ uest for Identity in Post $N$ ew 0 rder Indonesia (Ithaca: Cornell Southeast A sian Program, 2006); G reg Fealy, "H izbut Tahrir in Indonesia: Seeking a 'Total' Islamic Identity", dalam S. A kbarzadeh \& F. M ansouri. I slam and Political V iolence: M uslim D iaspora and Radicalism in the West (London: I.B. Tauris, 2007); Syamsul Rijal, "Indoctrinating Muslim Youths: Seeking Certainty through An-Nabhanism". Alfami'ah, Vol. 49, No. 2, (2011), hlm 253-280; Eva F. Nisa, "Embodied Faith: A gency and O bedience among Face-veiled U niversity Students in Indonesia", The A sia Pacific Journal of A nthropology, Vol. 13, No. 4, (2012), hlm 366-381; N ajib Kailani, "Forum Lingkar Pena and M uslim Youth in Contemporary Indonesia". Review of Indonesian and M alaysian A ffairs, Vol. 46, No.1, (2012), hlm 33-53; M inako Sakai, "Preaching to Muslim Youth in Indonesia: The 'D akwah' Activities of Habiburrahman El Shirazy", Review of Indonesian and M alaysian A ffairs, Vol. 46, No.1, (2012), hlm 9-31.

3 A rif Zamhari dan Julia Day H owell, "Taking Sufism to the Streets: Majelis Zikir and M ajelis Shalawat as N ew Venues for Popular Islamic Piety in Indo- 
nesia", Review of Indonesian and M alaysian Affairs, Vol. 46, N o. 2, hlm 47-75.

4 Ismail Fajrie Alatas, "Becoming Indonesians: The Ba'A lawi in the Interstices of the Nation", Die W elt de Islams, Vo. 51 (2011), hlm 45-74.

5 I bnu Fuad Almusawa, M eniti Jalan Pemuda Nabawi: Biografi Pendiri M ajelis Rasulullah Saw H abib M unzir bin Fu'ad A Imusawa (Jakarta: M ajelisR asulullah, 2014), hlm 5.

6 Ismail Fajrie Alatas, Securing Their Place: The Ba'alawi, Prophetic Piety and IsIamic Resurgence. M A Thesis. National U niversity of Singapore, (2008), hlm 96.

7 Wawancara, Tim IT Majelis Rasulullah, 50 ktober 2013.

8 Ahmad Fadhli, U lama Betawi (Studi tentang Jaringan U lama Betawi dan K ontribusinya terhadap Perkembangan Islam A bad ke19 dan 20) (Jakarta: M anhalun Nasyi-in Press. 2011), hlm 59.

9 Wawancara, Indry, 190 ktober 2013.

10 Kemendagri. "Profil Propinsi DKI Jakarta", diakses pada tgl 5 Januari 2015, dari http:// www.kemendagri.go.id/ pages/ profil-daerah/ provinsi/ detail/ 31/ dkijakarta

11 Roman Cybrwsky\& Larry R. Ford, "C ity Profile: Jakarta", C ities, Vol. 8, No. 3, hlm 199-210.

12 Bappeda Jakarta. "Statistik kemiskinan", diakses pada tgl 5 Januari 2015, dari http:// bappedajakarta.go.id/?page id =1124

13 Lyn Parker \& Pam Nilan, A dolescents in Contemporary Indonesia (N ew York: Routledge, 2013).

14 A tmodiwirjo, "The U se of U rban Public Places in Jakarta for Adolescents' $\mathrm{H}$ anging $\mathrm{O}$ ut", Journal of A sian A rchitecture and Building E ngineering, $\mathrm{V} 0.7, \mathrm{NO}$. 2, (2008), hIm. 345.

15 Parker \& Nilan, A dolescents in Contemporary Indonesia.

16 M anja Stephan, "Education, Youth, and Islam: The G rowing Popularity of Private Religious Lessons in D ushanbe, Tajikistan", C entral A sian Survey, Vol. 29, N o. 4, (2010), hlm 475; B. Bradford Brown \& Reed W. Larson, "The Kaleidoscope of A dolescence: Experiences of the W orlds Youth at the Beginning of the $21^{\text {st }}$ Century", dalam B. Bradford Brown, Reed W. Larson, and Saraswathi (Eds.). The World's Youth: A dolescence in Eight Regions of the $G$ lobe (C ambridge: C ambridge U niversity Press, 2002), hlm 9-10.

17 Ben W hite, "G eneration and Social C hange: Indonesian Youth in Comparative Perspective", dalam Kathryn Robionson, Youth I dentities and Social Transformations in M odern Indonesia (Leiden: Brill, 2015), p. 14.

18 G.S. Colin, Encyclopedia of Islam (Leiden: E.J. Brill,1978), hIm 1032.

19 Liyakat N. Takim, The H eirs of the Prophet: $\mathrm{C}$ harisma and Religious A uthority in Shi'ite Islam (Albany: State U niversity of N ew York Press, 2006), hIm 45.

20 Joseph W. M eri, "A spects of Baraka (Blessings) and Ritual Devotion A mong M edieval M uslims and Jews", M edieval Encounters, Vol. 5, No.1, (1999), hlm 46-69.

21 Sumit K. Mandal, "Popular Sites of Prayer, Transoceanic Migration, and 
Cultural Diversity: Exploring theSignificance of Keramat in Southeast A sia", M odern A sian Studies, Vol. 46, N o. 2, (2012), hlm 357.

22 Kominfo, "Pengguna Internet di Indonesia 63 Juta 0 rang", (2013), diakses pada tgl 5 Januari 2015, dari http:// kominfo.go.id/ index.php/ content/ detail/3415/Kominfo+\%3A +Pengguna+Internet+di +1 ndonesia+63+Juta+ O rang/ $0 /$ berita satker

23 Parker \& N ilan, A dolescents in Contemporary Indonesia, hIm.166.

24 https:/ / www.facebook.com/M ajelis-Rasulullah-SAW, diaksespada tgl 30 September 2013.

25 EmileD urkheim, "The ElementaryForms of Religious Life", dalam M ichael Lambek (Ed.). A Reader in the Anthropology of Religion, (London: Blackwell, 2002), hlm 34-47.

26 M ara Einstein, $B$ rands of Faith: $M$ arketing Religion in Commercial $A$ ge (London and New York: Routledge, 2008), hlm. 71-72.

27 Julian M illie, "Islamic Preaching and Women's Spectatorship in West Java". The A ustralian Journal of A nthropology, Vol. 22, N o. 2, (2011), hlm 156.

28 A sef Bayat, Being Young and M uslim: N ew Cultural Politics in the G lobal South and $\mathrm{N}$ orth (N ew York: 0 xford U niversity Press, 2010), hlm 8.

$29 \mathrm{Ibid}, \mathrm{h} / \mathrm{m} 28$.

30 Wawancara, Syaiful Anwar, 16 D esember 2013.

31 Wawancara, Puput, 20 September 2013.

32 Tim M ilist MR, M engenal L ebih D ekat H abib M unzir A Imusawa (Jakarta: M ajelis Rasulullah SAW, 2013), hlm. 42.

33 Pierre Bourdieu, "The Forms of C apital", diterjemahkan oleh Richard Nice, dalam $\mathrm{H}$ andbook of Theory of Research for the Sociology of Education (T.t: $G$ reenword Press). Lihat juga D avid Swartz, "Bridging the Study of C ulture and Religion: Pierre Bourdieu's Political Economy of Symbolic Power", Sociology of Religion, Vol. 57, N o. 1, (1996), hlm 71-85; Terry Rey, "M arketing the Goods of Salvation: Bourdieu on Religion", Religion, 34, (2004), hlm 331343.

34 Wawancara, Syaiful Anwar, 16 D esember 2013.

35 Guntur \& Tim Majelis Rasulullah, H abib M unzir M enanam untuk Para K ekasih Rasulullah (Jakarta: Q ultum M edia, 2013), hlm 31.

36 A lexander Knysh, "The Tariqa on a Landcruiser: The Resurgence of Sufism in Yemen", The M iddle East Journal, Vol. 55, No. 3, (2001), hlm. 408.

\section{DAFTAR PUSTAKA}

A latas, I.F. 2008. Securing Their Place: The Ba'alawi, Prophetic Piety and Islamic Resurgence. M A Thesis. National U niversity of Singapore.

2011. Becoming Indonesians: The Ba'A lawi in the Interstices of the $\mathrm{Na}$ tion. Die Welt de Islams, 51, 45-74.

Atmodiwirjo, P. 2008. The U se of U rban Public Places in Jakarta for Adolescents' $\mathrm{H}$ anging $\mathrm{O}$ ut. Journal of $\mathrm{A}$ sian A rchitectureand Building E ngineering, 7 (2), 339-346. 
Bayat, A. 2010. Being Young and M uslim: N ew C ultural Politics in the G lobal South and $N$ orth. N ew York: $O$ xford U niversity Press.

Bourdieu, P. 1986. The Forms of Capital. Translated by Richard Nice. Dalam $\mathrm{H}$ andbook of Theory of Research for the Sociology of Education. N .p.: G reenword Press.

Brown, B.B. \& Larson, R.W. 2002. The Kaleidoscope of Adolescence: Experiences of the Worlds Youth at the Beginning of the $21^{\text {st }} \mathrm{C}$ entury. D alam B.B. Brown, R.W. Larson, and T.S. Saraswathi (Eds.). The World's Youth: A dolescence in $E$ ight Regions of the $G$ lobe. $C$ ambridge: $C$ ambridge $U$ niversity Press.

Bunell, T. \& Miller, M.A. 2011. Jakarta in Post-Suharto Indonesia: Decentralisation, N eo-Liberalism and G lobal C ity Aspiration. Space and Polity, 15(1), 35-48.

Cybrwsky, R. \& Ford, L.R., "C ity Profile: Jakarta”, Cities 8(3), hlm 199-210.

Durkheim, E. 2002. The Elementary Forms of Religious Life. In M. Lambek (Ed.). A Reader in the A nthropology of Religion (pp. 34-47). London: Blackwell.

Einstein, M. 2008. B rands of Faith: M arketing Religion in C ommercial A ge. London and New York: Routledge.

Fadhli, A . 2011. U lama B etawi (Studi tentangJaringan U lama B etawi dan K ontribusinya terhadap Perkembangan Islam A bad ke19 dan 20. Jakarta: Manhalun Nasyi-in Press.

Fealy, G. 2007. H izbut Tahrir in Indonesia: Seeking a 'Total' I slamic Identity. Dalam S. Akbarzadeh \& F. M ansouri. Islam and Political Violence: M uslim Diaspora and Radicalism in the West. London: I.B. Tauris.

H asan, N . 2006. Laskar Jihad: I slam, M ilitancy, and the Q uest for I dentity in Post-N ew 0 rder Indonesia. I thaca: Cornell Southeast A sian Program.

Kailani, N . 2012. Forum Lingkar Pena and M uslim Youth in Contemporary Indonesia. Review of Indonesian and M alaysian Affairs 46 (1), 33-53.

Knysh, A. 2001. TheTariqa on a Landcruiser: The Resurgence of Sufism in Yemen. The M iddle E ast Journal, 55(3), 399-414.

M andal, S.K. 2012. Popular Sites of Prayer, Transoceanic M igration, and C ultural Diversity: Exploring the Significance of Keramat in Southeast Asia. M odern A sian Studies, 46(2), 355-372. (2011).

M eri, J.W . 1999. A spects of Baraka (Blessings) and Ritual D evotion A mong M edieval M uslims and Jews. M edieval Encounters, 5(1), 46-69.

M illie, J. 2011. I slamic Preaching and Women's Spectatorship in West Java". The A ustralian Journal of A nthropology, 22 (2), 151-169.

Nisa. E.F. 2012. "Embodied Faith: A gency and O bedience among Face-veiled U niversity Students in Indonesia", The A sia Pacific Journal of A nthropology, 13: 4, 366-381.

Parker, L. \& N ilan, P. 2013. A dolescents in Contemporary Indonesia. N ew York: Routledge.

Rey, T. 2004. M arketing the G oods of Salvation: Bourdieu on Religion. Religion, $34,331-343$.

Rijal, S. 2011. Indoctrinating Muslim Youths: Seeking Certainty through An- 
Nabhanism. Alfami'ah, 49 (2), 253-280.

Rosyad, R. 1995. A Q uest for Truel slam: A Study of the Islamic ResurgenceM ovement among the Youth in Bandung, Indonesia. C anberra: ANU E-Press.

Sakai, M . 2012. "Preaching to M uslim Youth in Indonesia: The 'D akwah' Activities of H abiburrahman El Shirazy", Review of Indonesian and M alaysian A ffairs, 46(1), 9-31.

Swartz, D.1996. Bridging the Study of Culture and Religion: Pierre Bourdieu's Political Economy of Symbolic Power. Sociology of Religion, 57(1), 71-85.

Takim, L. N. 2006. The H eirs of the Prophet: C harisma and Religious A uthority in Shi'ite Islam. A lbany: State U niversity of N ew York Press.

Tim Milist M R. 2013. M engenal Lebih D ekat H abib M unzir A Imusawa. Jakarta: $M$ ajelis Rasulullah SAW.

W hite, B. 2015. "Generation and Social Change: Indonesian Youth in Comparative Perspective". Kathryn Robionson, Youth Identities and Social Transformations in M odern Indonesia. Leiden: Brill.

Zamhari, A.\& H owell, J.D. 2012. Taking Sufism to the Streets: M ajelis Zikir and $\mathrm{M}$ ajelis Shal awat as N ew Venues for Popular Islamic Piety in Indonesia. Review of Indonesian and M alaysian Affairs, 46(2), 47-75.

\section{Websites:}

Bappeda Jakarta. 2014. Statistik kemiskinan. Diakses pada tgl 5 Januari 2015, dari http:// bappedajakarta.go.id/ ?page id=1124

Isparmo. 2014. Data Statistik Pengguna Facebook 2014 di Indonesia. Diakses pada tgl 5 Januari 2015, dari http:// isparmo.web.id/ 2014/ 10/ 14/ data-statistikpengguna-facebook-2014-di-indonesial

Kemen dagri. T.t. Profil Propinsi D KI Jakarta. Diakses pada tgl 5Januari 2015, dari http:// www.kemendagri.go.id/ pages/ profil-daerah/ provinsi/detail/31/ dkijakarta

Kominfo. 2013. Pengguna Internet di Indonesia 63 Juta 0 rang. Diakses pada tgl 5 Januari 2015, dari http:// kominfo.go.id/ index.php/ content/ detail/3415/ Kominfo $+\% 3 \mathrm{~A}+$ Pengguna+Internet $+\mathrm{di}+1$ ndonesia $+63+$ uta $+0 \mathrm{rang} / 0 /$ berita satker

\section{Wawancara}

Indry Rahmawati, 19 o ktober 2013

Puput, 20 September 2013

Syaiful A nwar, 16 D esember 2013

Tim IT Majelis Rasulullah, 50 ktober 2013. 


\title{
Rekonstruksi Nalar Keagamaan; Ikhtiar Menemukan Konteks A gama Bagi Pengembangan Sains
}

DOI 10.18196/AIIJIS.2018.0087.190-218

\author{
MOHAMMAD MUSLIH \\ Universitas Darussalam Gontor \\ Email: muslih@unida.gontor.ac.id
}

\section{ABSTRACT}

The development of religion-based science was not only a scientific problem, but also a social and Islamic problem. The problem is not merely related to efforts of finding a basis of philosophy of science and methodology support, but also an attempt to reconstruct public mind set and understanding of I slam. This article will look at some of the key concepts of Islam, which provide a fertile ground for the development of science, although some might view these concepts as barriers for the growth and development of science. The fundamental solution to this problem is urgent to be given to find a wider space for a negotiation between religion (Islam) and science. In the end of the day, a higher effort to develop I slamic science with its religious and scientific ground can be exerted and achieved.

K eyword: Ethics, Religious M ission, E pistemology, A ct of W orship, Paradigm

\section{ABSTRAK}

Pengembangan sains berbasis agama, ternyata bukan hanya problem keilmuan semata, tetapi sekaligus merupakan problem kemasyarakatan dan keislaman. Sehingga persoal annya bukan hanya terkait upaya menemukan basis filsafat ilmu dan dukungan metodologi, tetapi juga upaya melakukan rekonstruksi pola pikir masyarakat dan pemahaman keislaman. Artikel ini akan melihat beberapa konsep kunci keislaman, yang mestinya merupakan "tempat" yang subur bagi pengembangan sains, namun kenyataannya banyak dimengerti sebagai penghambat, kalau tidak malah sebagai penghalang, bagi tumbuh-kembangnya sains dalam Islam. Penyelesaian secara mendasar terhadap problem tersebut mendesak untuk segera diberikan, untuk menemukan kemungkinan irisan dan area negosiasi dengan sains, agar upaya besar pengembangan sains Islam dapat landing dengan landai.

Keyword: A khlak, D akwah, Epistemologi, I badah, Paradigma 


\section{PENDAHULUAN}

Gagasan untuk mempertemukan antara sains dan agama telah berkembang menjadi suatu wacana keilmuan, seperti Islamisasi ilmu, pengilmuan Islam, integrasi-interkoneksi, integrasi ilmu dan agama, dan lain-lain. Dalam perspektif Filsafat IImu, wacana keilmuan terkait integrasi agama dan sains itu baru mempunyai signifikansi yang sangat tinggi,jika berlanjut dengan lahirnya 'produk' sains baru yang menempatkan agama sebagai bagian tak terpisahkan dari bangunan keilmuannya (scientific building). Untuk itu wacana keilmuan juga mesti memperkokoh diri dan melangkah ke tahap berikutnya yaitu menjadi paradigma keilmuan (scientific paradigm). Namun harus diakui, hingga hari ini, nyatanya ada banyak nada pesimistis terhadap kemungkinan lahirnya sains baru berbasis agama. Alasan yang paling sederhana adalah bahwa sains itu bersifat sainstifik, sedangkan agama adalah ajaran yang normatif-teologis, bahkan lebih tradisional lagi, agama itu tidak lebih dari soal doa, membentengi iman, meratapi dosa, dan menjaga akhlak, terdepan membenci Barat, dan menolak keras teori evolusi dan sains modern pada umumnya. Dengan pandangan seperti itu, sudah bisa dipastikan penyatuan keduanya tidak akan terjadi, dan apa yang disebut dengan sains Islam juga tidak akan pernah terwujud. Beberapa hal ini sekaligus menandakan bahwa pengembangan sains berbasis agama, bukanlah problem keilmuan semata, tetapi sekaligus merupakan problem kemasyarakatan dan keislaman. Sehingga persoalannya bukan hanya terkait upaya menemukan basis filsafat ilmu dan dukungan metodologi ilmiah, tetapi juga upaya melakukan rekonstruksi pola pikir masyarakat dan pemahaman keislaman.

Artikel ini akan melihat beberapa konsep kunci keislaman, yang mestinya merupakan "tempat" yang subur bagi pengembangan sains, namun kenyataannya banyak dimengerti sebagai penghambat, kalau tidak malah sebagai penghalang, bagi tumbuh-kembangnya sains dalam Islam. Penyelesaian secara mendasar terhadap problem tersebut mendesak untuk segera diberikan, untuk menemukan kemungkinan irisan dan area negosiasi dengan sains, agar upaya besar pengembangan sains Islam dapat landing dengan landai.

\section{SAINS, BUKAN SOAL KEYAKINAN?}

Kata "sains" diadaptasi dari kata Inggris "science" yang sebenarnya berasal dari bahasa Latin "scientia" yang berarti mengetahui atau pengeta- 
huan (to know, knowledge) dan perkataan Latin juga "scire" yang berarti belajar (to learn). ${ }^{1}$ Dua istilah itu identik atau bisa diidentikkan dengan istilah Arab, 'alima, 'ilm (mengetahui, pengetahuan)² dan thalab al'-ilm (belajar atau mencari ilmu), yang dalam tradisi Islam, masih dibedakan dengan istilah idrak (persepsi), yang bertumpu pada pencerapan inderawi dan 'irfan (pengenalan), yang bertumpu pada pengalaman spiritual, sebagaimana dalam tradisi sufi, ${ }^{3}$ sementara 'ilm disebut sebagai pengetahuan yang bertumpu pada akal atau gabungan antara akal dengan sensibilitas.

Pengertian sains sebagai pengetahuan atau sebagai bagian dari pengetahuan ini tampaknya merupakan pengertian paling dasar, sehingga ciri-ciri dasar dari apa yang disebut pengetahuan melekat pada sains, meski begitu sains mempunyai ciri-ciri khusus yang berbeda dengan pengetahuan jenis yang lain. ${ }^{4}$ Selain itu pengertian sains sering dikaitkan dengan ruang lingkup atau isu yang juga menjadi ciri khasnya, yaitu sebagai aktivitas ilmiah, sebagai metodologi, dan sebagai disiplin ilmu.

Secara konseptual, apa yang disebut pengetahuan merupakan hasil akhir dari proses penyimpulan yang masuk akal dari berbagai bahan informasi dan pengalaman, ${ }^{5}$ sebagai keputusan 'pikiran' dan mempengaruhi sikap perilaku, di mana proses dan bahan-bahannya bisa dipertanggungjawabkan, dan dapat diuji ulang. Pengetahuan, dengan demikian, berbeda dengan sekedar informasi atau pengalaman itu sendiri, dan jauh sekali bedanya dengan keyakinan apalagi keimanan. Keimanan itu pengakuan hati yang sudah terang benderang bagi akal, sehingga bagi akal, tidak perlu ada pengujian, akali dan indrawi, atau mengujinya adalah sebuah kemubadziran. Dalam banyak hal, orang mendapatnya barulah berupa informasi, tapi sudah merasa di tingkat punya pengetahuan dan sikapnya sudah seperti banyak tahu. Ada juga, orang mendapatnya barulah berupa pengetahuan, sudah merasa dirinya telah sampai ke tingkat yang kaya pengalaman dan sikapnya itu sudah seperti orang "bijak" yang hidupnya paling matang. Dan, banyak yang merasa punya pengetahuan (ilmu), lalu menularkannya (sharing, berbagi), padahal itu barulah berupa informasi, atau justru malah berupa keimanan.

Secara epistemologis, proses terbentuknya pengetahuan karena manusia mempunyai "pengetahuan" apriori yang dengannya pengetahuan apapun lalu dideduksikan. "Pengetahuan" apriori itu merupakan ide bawaan "innate ideas" (Descartes) yang clear and distinct, ${ }^{6}$ substansi 
ilahiyah (Spinoza), ${ }^{7}$ merupakan principles of nature and the grace founded on reason (Leibniz), ${ }^{8}$ dan prinsip-prinsip dasar rasio itu sebagai bawaan untuk pikiran manusia (Christian Wolff). ${ }^{9}$ Beberapa pemikiran demikian, dalam kajian filsafat disebut dengan aliran rasionalisme, yaitu aliran filsafat yang melihat pentingnya peran 'akal', 'kesadaran', 'idea', 'substansi', 'form', dalam proses terbentuknya pengetahuan.

Berbeda dengan rasionalisme yang memposisikan rasio sebagai sarana utama bagi terbangunnya pengetahuan, empirisisme justru memilih pengalaman inderawi sebagai sumber utama pengenalan. Di sini, pengalaman inderawi dinilai sebagai awal dari segala pengenalan, sementara pengenalan intelektual merupakan tahap lanjutan sebagi semacam penggabungan data-data inderawi yang sama, dengan cara yang berbeda. ${ }^{10}$ Filsuf yang paling terkenal menawarkan gagasan empirisisme adalah David Hume. Bagi Hume, isi pemikiran itu seluruhnya berasal dari "persepsi." Persepsi itu terdiri dari dua tingkatan, yaitu kesan-kesan (impressions) dan gagasan (ideas). Yang pertama bisa disebut 'pengalaman indrawi' dan yang kedua merupakan konsep atau 'makna'. Hume membedakan dua jenis kesan (impressions), yaitu sensasi dan refleksi, serta dua jenis gagasan (ideas), yaitu memory dan imaginasi. Kesan sensasi muncul dari jiwa yang tidak diketahui sebab musababnya, sedang kesan refleksi diturunkan gagasan-gagasan. M emory memiliki posisi yang teratur. Adapun imajinasi adalah jenis gagasan yang mengkombinasikan ide (gagasan) yang berasal dari kesan-kesan secara asosiatif, dengan mengikuti hukum asosiasi. Menurut Hume, manusia memiliki kecenderungan intern untuk menghubunghubungkan gagasan-gagasan yang ada menurut "keserupaan", "kedekatan", atau hubungan "efek". Tiga hal inilah yang disebut "relasi natural". Dengan dasar epistemologinya ini, Hume menolak konsep substansi dan konsep kausalitas, dari pengikut rasionalisme ${ }^{11}$.

Seperti sering terjadi, kesalahan memahami Hume dan pemikiran empirisisme pada umumnya adalah karena menganggap Hume hanya berhenti di pengalaman inderawi, tanpa melihat kekompleksan proses selanjutnya. Selain itu jika pemikiran empirisisme ini memang lemah atau ditemukan banyak kelemahan, tidak semestinya berlanjut dengan menafikan dan mencurigai kerja indrawi sebagai sarana ilmiah. Penglihatan manusia sudah tentu terbatas, demikian pula pendengaran, penciuman, perabaan, dan perasaannya, sementara pemikiran manusia itu luas atau lebih luas. Maka merenungkan pengalaman indrawi, berarti membawanya 
kepada pengetahuan dan pelajaran yang sangat luas, dan akan membuatnya lebih berarti bagi kehidupan. ${ }^{12}$ Namun demikian, hanya karena ada percobaan, pensil ditaruh di gelas berisi air putih, yang tampak seperti bengkok, orang lalu begitu menyepelekan panca indra, mencurigai cerapan indrawi, dan memusuhinya, karena dianggap biang kebohongan, dan tidak bisa mengantarkan ke pengenalan terhadap Tuhan. Termasuk pandangan-pandangan yang mencoba menunjukkan kekhasan dan kebermaknaan panca indra ${ }^{13}$ dianggap merusak iman, dan dianggap bertentangan dengan agama. Padahal pancaindra merupakan anugrah ilahiyah, yang luar biasa, yang mesti dimaksimalkan perannya, bahkan hingga sampai ke pengenalan terhadap kebesaran Tuhan.

Mata atau lebih tepatnya indra penglihatan, sudah tentu, adalah hal pokok yang membuat manusia menjadi makhluk yang melihat, yang punya daya melihat. Telinga (indra pendengaran) adalah hal pokok yang membuat manusia sebagai makhluk yang mendengar, yang punya daya mendengar. Maka, indra penglihatan dan indra pendengaran itu bukanlah sekedar 'bagian' dari manusia, tapi manusia itu sendiri atau diri manusia itu sendiri. Rasio adalah hal pokok yang membuat manusia menjadi makhluk yang berpikir, yang punya daya berpikir, maka rasio adalah diri manusia itu sendiri, dan berpikir adalah aktivitas wajar manusia yang manusiawi. ${ }^{14}$

Jika ada pemerhati ilmu, meremehkan mata, telinga, dan rasio sebagai sarana ilmiah, berarti meremahkan dirinya sendiri. Jika mereka mencurigai mata, telinga, dan rasio, bararti mencurigai dirinya sendiri, jika mereka menolaknya karena dianggap hanya akan menghasilkan pengetahuan yang salah, yang menjerumuskan pada kesalahan, berarti telah menolak dirinya sendiri. Diri manusia yang meremehkan, mencurigai, dan menolak dirinya sendiri, tentu itu bukan hanya sebagai diri yang terkandung salah, tetapi benar-benar diri yang salah, benar-benar diri yang telah error. Pada pemerhati ilmu yang "religius", bisa lebih jauh lagi, mereka tidak hanya berhenti dengan meremehkan, mencurigai, dan menolak mata, telinga, dan rasio sebagai sarana ilmiah, tapi mereka bersikap seperti itu, karena lebih memilih kabar agama, dan ajaran agama, sebagai sarana ilmiah, yang memang merupakan kebenaran itu, dan yang pasti benar. Yang mereka lupa adalah, bisakah kabar dan ajaran kebenaran yang benar itu dapat sambung, ketemu, kompetabel, apalagi disebut menyatu, dengan diri yang salah dan error itu. Mestinya benarnya diri, atau hilangnya keerror-an diri, sebagai prasyarat untuk menyambungnya dan menyatunya 
kabar dan ajaran agama yang benar itu dengan dirinya.

Pengetahuan atau ilmu pengetahuan itu bukan soal yakin apa tidak yakin, juga bukan soal paham apa tidak paham, tapi soal meyakinkan apa tidak, dan soal memahamkan apa tidak, tentu pada orang-orang yang waras akalnya. Untuk maksud itu diperlukan bukti-bukti empiris dan penjelasan-penjelasan rasional. Meskipun perlu dicatat, bagaimana bisa yakin dan meyakinkan dan bagaimana bisa paham dan memahamkan jika tidak melalui proses yang bertanggungjawab.

\section{PROBLEMATIKA NALAR KEAGAMAAN, KONTEKS AGAMA BAGI PENGEMBANGAN SAINS}

Seperti diuraikan sebelumnya, bahwa sains seringnya diposisikan secara berhadap-hadapan dengan agama. Oleh karena itu, semangat mempertemukan sains dengan agama, mesti dibarengi dengan berjalannya nalar agama dan sekaligus nalar sains, agar pengembangan sains tidak jatuh kepada "agamaisasi" sains atau malah terjadi "sainisasi" agama, yang menganggap agama dan sains dapat saling mengisi sebab berada pada posisi setara. Imre Lakatos, dalam salah satu karyanya, ada satu sub bab khusus, yaitu "Science: Reason or Religion?", ${ }^{15}$ bahwa sains tidak akan pernah menghindar dari upaya kritik, sebab sifatnya yang syarat penyangkalan (refutability), penyalahan (falsifiability), bahkan dapat terjadi revolusi sains. Namun pada saat yang sama, sains dapat saja mempertahankan diri dari berbagai bentuk kritik itu, atau karena memang sengaja dipertahankan 'mati-matian'. Jika memang demikian kondisinya, disadari atau tidak, sains akan hilang karakter keilmiahannya dan lalu "naik" derajatnya menjadi "agama".Oleh karena itu, posisi agama bukanlah sebagai alat pembenaran bagi sains. "The religion that is married to science today will be a widow tomorrow", demikian Holmes Rolston III $^{16}$. Agama yang menyatu dengan sains, pada saatnya nanti keduanya akan 'bercerai' sehingga menjadi mantan,oleh karena itu, antara agama dan sains, mestinya harus tetap menjaga keotonomian integritas dan ketahanan masing-masing, bukan disatukannya. ${ }^{17}$

Sebagai bagian dari aktivitas kemanusiaan atau bahkan kehidupan manusia, pengembangan sains, bagaimanapun, tetap harus berada dalam konteks sosial, dan sebisa mungkin diletakkan pada konteks agama, di satu sisi agar tidak terlepas dari akar sosial budaya sebagai basis etis, dan agar tetap bergelimang makna dalam ruang religiusitas, pada sisi yang 
lain. Meski demikian, perlu sekali lagi ditegaskan bahwa problem disintegrasi antara sains dan agama, jelas merupakan problem kemanusiaan, terkait sikap, pola pikir, dan subjektivitas manusia.Sebab, dalam konteks Islam, antara ilmu dan agama, termasuk antara ilmu agama dan ilmu umum, bukanlah telah benar-benar terpisah, baik pada wilayah doktrin maupun secara historisitas-peradaban, nyatanya menunjukkan bahwa. Dalam tradisi Islam, bahkan ilmu itu satu sisi dari agama, maka berilmu itu juga merupakan ujud dari beragama. Jikalau keduanya tampak terjadi keterpisahan tidak lain karena pandangan agamawan, perspektif ilmuwan, dan persepsi masyarakat muslim telah memisahkan, bahkan telah mempertentangkan keduanya, namun sekarang, pandangan, perspektif, dan persepsi mereka itu sudah mulai mereka koreksi sendiri.

Sebagai upaya menemukan konteks bagi pengembangan sains, di bawah ini akan dibahas beberapa isu keislaman, yang pada dasarnya merupakan isu populer, bahkan isu awam, dan sangat boleh jadi tidak merupakan masalah serius bagi kalangan ilmuwan, tetapi jika diabaikan, dapat saja menjadi semacam 'duri dalam daging' bagi pengembangan sains dalam masyarakat muslim.

\section{Nalar Teks}

Pembahasan ini tidak dimaksudkan untuk mengkaji bagaimana proses terbangunnya kesadaran teks dalam kehidupan masyarakat muslim, akan tetapi lebih menunjukkan kepada pengakuan bahwa nalar teks telah begitu kokoh sehingga mempengaruhi pola pikir, sikap, dan perilaku umat Islam, bahkan pola hidup mereka, baik sebagai individu, masyarakat sosial, maupun dalam bentuk tradisi dan budaya. Alasan yang paling mendasar adalah bahwa di dalam Islam ada ajaran iman terhadap kitab suci, kemudian ada ajaran bahwa al-Qur'an dan hadits itu sumber hukum dan ajaran Islam,pedoman hidup manusia sekaligus sebagai sumber ilmu pengetahuan. Semua ini menjadikan al-Qur'an dan hadits memiliki posisi sentral dalam kehidupan umat Islam. Terhadap kedua sumber agama itu sudah tentu ada beragam sikap dan 'perlakuan' dari umat Islam, mulai dari sikap yang harfiah, dzahiriyah, hingga yang ma'nawiyah; dari yang menggunakan jalur tafsir, hingga yang memasuki jalur ta'wil ilmu; dari yang menjustifikasi temuan teori ilmiah dengan ayat al-Qur'an, yang menggali konsep-konsep embrional dari al-Qur'an, hingga yang lanjut mengembangkan kajian ilmu-ilmu keislaman (Islamic Studies). Pola 
kehidupan seperti ini yang kemudian dikenal dengan istilah hadarat alnash. ${ }^{18}$

Dalam pola kehidupan seperti itu, menjadi wajar jikalau umat Islam meniscayakan dirinya untuk selalu berpikir dalam kerangka teks; ${ }^{19}$ memulangkan segala persoalan kepada teks dan dalam kerangka teks. Begitu pula dalam kaitannya dengan pengembangan ilmu, dan aktivitas ilmiah pada umumnya, umat Islam akan selalu mengaitkannya dengan nash alQuran dan atau al-Hadits, bahkan kerja saintifik harus berbasiskan pada kedua sumber pokok itu. Persoalannya, ilmu adalah aktivitas manusiawi yang tidak kebal terhadap upaya kritik, falsifikasi, dan refutasi, sedangkan nash tidaklah demikian. Oleh karena itu pola hubungan antara keduanya mesti ditemukan, agar pengembangan sains tidak semakin jauh meninggalkan konteks agama, dan sebaliknya agama juga terbuka terhadap pengembangan dan perkembangan sains. Persoalan selanjutnya, bagaimana seharusnya mengembangkan sains berbasis nash, atau bagaimana memposisikan nash dalam rancang bangun pengembangan sains.

Selama ini, upaya mengintegrasi al-Qur'an dengan sains dilakukan dengan mengakarkan temuan-temuan ilmiah terhadap ayat-ayat kitab suci, atau dengan menafsirkan ayat kitab suci secara ilmiah (tafsir alilmu) dengan temuan teori ilmiah. Pola hubungan seperti ini, meski banyak dilakukan, umumnya masih bersifat individu atau bahkan secara sepihak, mufassir di satu sisi atau ilmuwan di sisi yang lain. Sudah tentu kondisi seperti begitu memiliki sejumlah kelemahan, terutama terkait kompetensi dan otoritas keilmuan masing-masing yang sebenarnya berbeda. Oleh karena itu dalam kerangka pengembangan ilmu berbasis al-Qur'an, mestinya bisa diupayakan dalam bentuk proyek institusional-kolektifkultural. Dalam arti, di situ ada kerangka kerja yang disepakati bersama, ada budaya ilmiah yang kokoh, dan merupakan kerja kolaborasi dari banyak ahli (mufassir dan ilmuwan). Dengan kata lain, upaya itu bukan proyek sepihak ilmuwan saja, apalagi jika kerja seorang diri secara pribadi, dan bisa dikatakan suatu pemaksaan jika secara pribadi harus mengakarkan temuan ilmiahnya pada ayat-ayat kitab suci, sementara tidak mempertimbangkan keterbatasan kompetensi dan otoritasnya terkait al-Qur'an dan ulum al-Quran. Hal yang sama, jika ada mufassir, apalagi jika hanya seorang diri, sementara ia harus menafsirkan ayat secara ilmiah menggunakan teori-teori ilmiah, padahal tidak memiliki kemampuan untuk menguji terkait rancang bangun teori yang digunakannya itu. Terkecuali 
mereka memiliki kemampuan luar biasa, menguasai al-Quran dengan segala makna kandungannya, sekaligus menguasai teori-teori ilmiah.

Oleh karena itu, pola institusional-kolektif-kultural layak dipertimbangkan. Dengan pola ini proyek kerja ilmiah demulai dengan terlebih dulu merumuskan basis nash, membangun konsep-konsep embrional (embryonal concepts) berdasar nash dengan memperhatikan ayat-ayat yang berkaitan dan pola-pola hubungannya, sehingga terbangun pemahaman komprehensip tentang isu tertentu, atau paling tidak dapat terhindar dari salah pengertian, karena ditinggalkannya ayat tertentu yang semestinya berkaitan. Setelah itu program kerja ilmiah dapat disusun, mulai jangka pendek, jangka menengah, sampai jangka panjang. Dalam praktiknya suatu kerja ilmiah, sudah tentu harus dijalankan dengan standar dan etika ilmiah dalam kerangka menjalankan grand project (al-masyru' al-kabir) yang telah disepakati dan ditetapkan bersama. Dengan pola seperti ini, apa yang kemudian disebut "sains berbasis al-Quran" atau sains yang dikembangkan dalam kerangka teks, menjadi mungkin terwujud, bahkan sains qur'ani yang tetap saintifik akan dapat dilahirkan.

\section{Nalar Iman}

Barangkali tidak berlebihan jika dikatakan bahwa hal pokok yang membedakan orang beragama dengan yang tidak beragama adalah iman. Meski demikian, orang yang mengatakan bahwa dirinya beriman, tetap tidak bisa dijadikan ukuran apalagi jaminan bahwa yang bersangkutan benar-benar beriman. Sebagai tanda dan ukurannya, iman mesti diwujudkan dalam sikap dan perbuatan baik dan benar, ${ }^{20}$ kerja produktif, ilmu yang berkembang, dan kebijaksanaan yang semakin indah. ${ }^{21}$ Iman itu mempercayai atau meyakini hal-hal pokok/mendasar, yang mana kemaslahatan hidup manusia bergantung padanya, dan akal mewajibkan keberadannya, sekalipun akal tidak meminta membuktikannya.Dalam ajaran Islam, iman itu masuk dalam wilayah ushul al-din (pokok-pokok agama), sehingga iman menjadi dasar dari pelaksanaan ajaran agama, dan hidup umat beragama, yang hakikat sebenarnya juga merupakan sendi-sendi kehidupan. Agama akan tegak kokoh jika iman kuat, begitu pula hidup dan kehidupan ini, sebaliknya, agama akan hancur berantakan dan roboh jika tidak ada iman, demikian juga dengan kehidupan ini.

Umat beragama tidak mungkin meninggalkan iman, seberapa pun intensitasnya. Semakin hidupnya dalam kerangka iman, berarti imannya 
semakin kokoh. Bahkan yang terjadi di tengah masyarakat, pembicaraan apapun, atau pertemuan apapun, termasuk ceramah yang disebut ceramah agama, akan terasa begitu 'agama' jika menyinggung isu iman. M eskipun ada juga yang lantas begitu mudahnya orang menyebut sebagai tidak agama, kadang dengan sebutan sekuler, humanis, bahkan ateis, jika di situ tidak disebut kata iman. Persoalannya, iman itu percaya, bahkan tinggal mempercayai, lalu di mana posisi usaha manusia, benarkah usaha itu tanda tidak iman, atau apakah dengan semakin berusaha keras itu berarti semakin jauh meninggalkan iman.

Persoalan tersebut sebenarnya persoalan klasik, tetapi harus diakui, hingga kini masih merupakan persoalan umum di masyarakat. Umat beragama, bagaimanapun, hidup di dua "alam" antara alam iman dan alam usaha, antara "hanya tinggal" mempercayai dan harus berpikir dalamdalam, dan usaha keras-keras. Memang logika sederhananya, jika lebih banyak yang "hanya tinggal" diimani, tentu lebih sedikit atau berkurang yang dipikirkan atau diusahakan. Dan sebaliknya, jika semakin banyak yang masuk dalam wilayah perenungan, akan berkurang yang ada dalam wilayah kepercayaan/keimanan. Sudah tentu itu logika sederhana atau logika awam, yang sangat perlu untuk dikoreksi, sebab itu bukan merupakan maksud dari adanya ajaran iman. M estinya semakin kuat iman, semakin berpikir keras, kerja keras, dan berprestasi.Pohon yang buahnya lebat, itu bukti akar-akarnya sehat dan kokoh. Jika ibarat ini digunakan, maka iman yang benar dan sehat, pasti lebat buahnya, dan buah iman itu adalah perbuatan baik (amal shalih) dan sikap yang mulia lagi memuliakan (akhlak karimah), serta tumbuhnya kreativitas dan produktivitas. Dengan pemahaman seperti itu, antara iman dan usaha, bukan hanya bisa berdamai dan berjalan seiring, tetapi bahkan keduanya adalah menyatu. Maka penyakit iman yang paling pokok adalah sikap malas, apalagi jika sikap itu diambil dengan dalih iman.

Jika problem iman dibawa ke wilayah pengembangan ilmu, maka persoalan dasar yang muncul kemudian, apa mungkin 'ajaran agama' yang berangkat dari keimanan, bisa disatukan dengan ilmu pengetahuan (dan filsafat) yang mendekatinya atau menyikapinya, mesti dimulai dengan mempertanyakannya atau meragukannya. Atas pertanyaan ini, di sini perlu ditegaskan, tidak bisa dibenarkan, karena sifat ilmu pengetahuan yang mesti dipertanyakan, atau dengan alasan 'keimanan' agama, lalu bersikap tidak mau ilmu pengetahuan atau malah menolaknya. Atau, karena sifat 


\section{$200 \mid$ нerum}

agama yang dimulai dengan iman itu, lalu apapun didekati dengan iman, hingga hal-hal yang mestinya perlu terlebih dulu dipertanyakan dari mana asal muasalnya.

Seperti telah dimaklumi bahwa sains adalah aktivitas manusiawi, usaha manusia yang dalam hal ini adalah ilmuwan. Maka sama seperti usaha manusia pada umumnya, kerja sains dapat menyatu dengan iman, dapat sebagai ujud dari keimanan. Jika sains menitikberatkan, bahkan menekankan hanya pada hal-hal yang ada, yang real, yang terbukti, yang observable, yang repeatable, yang measurable, dan yang predictable, sudah tentu itu bukan karena menolak adanya hal metafisik, dan bukan soal tidak iman terhadap adanya Tuhan dan hal-hal yang ghaib, tetapi soal, hal-hal apa yang mungkin ilmuwan bisa pertanggungjawabkan, atau lebih tepatnya, hal-hal apa yang ilmuwan tidak lagi bisa bohong, main-main, atau menyalahgunakan, dalam upaya meyakinkan dan memahamkan temuan ilmiahnya kepada masyarakat manusia di dunia ini. Maka, bahkan ahli metafisika dan kaum beriman, dalam rangka meyakinkan dan memahamkan apa yang diakuinya atau apa yang diimaninya, kalau itu memang harus dilakukan, juga memerlukan hal-hal apa yang sains lakukan, atau jika tidak, meski seandainya tidak ada maksud, tapi bisa saja dinilai sebagai bohong, main-main, dan modus.Top of Form.

Meskipun sains sejalan dan menyatu dengan iman, kerja sains itu bukan dimaksudkan untuk membuktikan keimanan, tertentu, karena keimanan bukan untuk dibuktikan, tapi justru menjadi orientasi dan alasan kuat untuk terlaksananya kerja-kerja sains, sekaligus sebagai kebulatan sikap yang mesti diambil oleh manusia sebagai ilmuwan. Sains itu 'bekerja' untuk mengungkap misteri ilmiah dan bahkan misteri kehidupan, untuk mengerti dan memahami hukum-hukum (alam dan sosial) sebagai pelajaran hidup, untuk memberi kemanfaatan sebesar-besarnya bagi kehidupan, bagi manusia dan kemanusiaan, serta kelestarianalam ini. Maka, secara singkat bisa dinyatakan, iman menjadi alasan kuat yang 'menggerakkan' aktivitas illmiah. Sebagai konsekuensinya, ilmuwan yang beriman, akan tinggi produktivitasnya.

Jika melihat kenyataan yang berkembang di masyarakat, nyatanya orang yang berpolapikir ilmiah tidak sulit menerima ajaran iman. Umumnya mereka lebih mudah mengerti dan menerima penjelasan-penjelasan tentang pentingnya beriman, setidaknya tidak sesulit orang yang katanya beriman jika diajak untuk berpola pikir ilmiah, malah ada yang meng- 
anggap pola pikir ilmiah itu bertentangan dengan iman, musuh iman, dan merusak iman, padahal seperti diuraikan di atas, mestinya antara beriman dan berpolapikir ilmiah itu berkaitan erat. Inilah sebenarnya maksud dari pernyataan bahwa keimanan Islam itu bukan buta, tetapi dengan ilmu, tidak dapat dipisahkan dengan ilmu, bahkan dengan amal. Pengembangan sains yang dibangun di atas kerangka pikir seperti itu, itulah sains Islam.

\section{Nalar Ibadah}

Dalam nash al-Qur'an sudah sangat jelas disebutkan, bahwa maksud dan tujuan penciptaan manusia adalah untuk beribadah kepada Allah. ${ }^{22}$ Ajaran ini mengharuskan umat Islam untuk hidup dengan seluruh aspek kehidupannya dalam kerangka ibadah. Namun pada tataran 'struktur' kesadaran, yang berkembang di masyarakat, apa yang dimaksud dengan ibadah itu menjadi begitu sempit pada hal-hal yang merupakan ibadah ritual, bahkan sebagai menyembah. Dengan kesadaran seperti itu, maka dengan mudahnya meletakkan banyak aspek kehidupan sebagai di luar ranah ibadah. Lebih jauh dari itu, umat Islam lalu terjebak pada sikap menyepelekan dan meninggalkan banyak bidang kehidupan yang sebenarnya justru merupakan area kehidupan yang sebenarnya, seperti bidang sosial, seni dan budaya, transportasi, teknologi informatika dan komunikasi, dll. Dalam kerangka pikir semacam ini, akan sulit agama menerima sains, dan sebaliknya sains juga akan sulit berdamai dengan agama, atau dalam hal ini, sains dalam konteks ibadah menjadi sesuatu yang mustahil.

Sudah tentu, paham keagamaan hingga menstruktur di kesadaran umat beragama terbentuk tidak dalam waktu singkat, tetapi melalui proses dan praktik kehidupan yang sangat panjang, dan ada banyak hal yang menjadi faktor pembentuknya, mulai yang terdekat misalnya ceramah-ceramah agama, nama mata pelajaran di sekolah, tata letak rak di toko buku, penamaan dan penyelenggaraan program studi dan fakultas, hingga pembidangan ilmu. Beberapa hal ini, sampai hari ini tetap menjadi semacam debu, yang meskipun lembut, dan mungkin sepele, tetapi dapat membuat 'pesawat' sains Islam yang telah terbang kemana-mana menjadi gagal landing, juga dapat membatalkan jadwal penerbangan karena debu itu akan merusak mesin. Maka mesti ada upaya pemaknaan baru terhadap apa itu ibadah.

Secara konseptual, apa yang dimaksud dengan ibadah pada dasarnya 


\section{2 s sumu}

amal perbuatan manusia yang diabdikan hanya untuk Allah. ${ }^{23}$ Sudah tentu ada syarat-syarat, baik dari sisi pelakunya, maupun pada sisi amal perbuatan itu sendiri, yang beberapa hal ini tidak dibahas di sini. Namun, kata kunci yang sangat pokok adalah diabdikan hanya untuk Allah. Kata kunci ini yang kemudian menjadi garis pembeda dari apa yang disebut ibadah dan yang bukan ibadah. Sebab pada kenyataanya, perbuatan manusia itu setidaknya ada tiga orientasi, yaitu orientasi pribadi, orientasi sosial (golongan, budaya, bangsa, dll), dan orientasi ketuhanan.Tiga orientasi ini mengambil pola berlapis, maka harus dimengerti, ini bukan soal bentuk perbuatan, tetapi soal derajat dan kualitas perbuatan. Jika suatu perbuatan, apapun, berorientasi pribadi, maka perbuatan itu akan terhalang untuk untuk dinilai sebagai perbuatan sosial, dan masih jauh untuk disebut sebagai bernilai ketuhanan. Selanjutnya, jika perbuatan dilakukan dengan berorientasi sosial, kemungkinan besar akan sekaligus bernilai pribadi, dalam arti ada pengaruh pribadi, ada kepuasan, kebahagiaan, dan kenikmatan pribadi, akan tetapi sangat jelas, itu belum sampai pada nilai ketuhanan. Dua lapis ini, jika mampu terlewati, suatu perbuatan akan memperoleh derajat dan kualitas tertinggi, sebab hanya diabdikan hanya pada Tuhan, inilah ibadah itu. Namun jika tidak terlewati, dua lapis itulah yang menjadi sekutu-Nya, yang menjadi penghalang untuk berserah diri.

Dengan kerangka pikir ini, maka perbuatan apapun dapat dinilai sebagai ibadah jika diabdikan hanya kepada Allah, tanpa pamrih pribadi, tanpa sekat kepentingan golongan, dan tanpa berharap ada keuntungan sosial. Sebaliknya, hingga shalat, puasa, haji, zakat, ibadah ritual lain, belum dapat dikatakan sebagai ibadah atau belum mencapai derajat sebagai ibadah jika belum dapat melewati sekat pribadi, golongan, dan sosial, makanya sering terdengar kata-kata 'haji politik', 'haji bisnis' dll. Tentu saja, dibanding berdagang, berbisnis, bertani, atau profesi lainnya, amalan seperti puasa, shalat, haji, zakat, membaca al-Quran, lebih dimungkinkan sampai ke derajat lillahi ta'ala, makanya beberapa amalan ini yang disematkan kata ibadah, meskipun baru benar-benar merupakan ibadah setelah melewati dua lapis di bawahnya. Lebih dangkal lagi, beberapa amalan 'ibadah' itu dilakukan hanya dengan pura-pura, akting, dan sandiwara, serta serius bagaikan upacara bendera.

Jika kerangka pikir ini dipertimbangkan, maka kawasan ibadah menjadi luas, dan bahkan ke seluruh aspek kehidupan manusia. Dalam arti, seluruh 
aspek kehidupan ini berkemungkinan sebagai ibadah, dan besar kemungkinan juga seluruh aspek kehidupan ini tidak sebagai ibadah, termasuk apa yang secara awam disebut sebagai ibadah. Dengan demikian, tidak berlebihan jika dikatakan, bahwa kerja sains yang selama mengindahkan tata kaidah ilmiah, mewarnainya dengan etika, menjiwainya dengan nilai ketuhanan, juga dapat diletakkan dalam kerangka ibadah dan sebagai ibadah pula.

\section{Nalar A khlak}

Akhlak menempati posisi sentral dalam agama Islam, di samping ibadah dan iman (aqidah). Akhlak adalah medan bersikap dan berkarakter benar sekaligus baik, ibadah adalah medan berbuat dan berperilaku benar sekaligus baik, dan iman adalah medan berpikir dan berrefleksi benar sekaligus baik, sedangkan agama adalah medan berhidup dan menjalani kehidupan benar sekaligus baik. Oleh sebab itu, dalam iman ada akhlak dan ibadah, dalam akhlak ada iman dan ibadah, dan dalam ibadah ada iman dan akhlak, sebagaimana berpikir, bersikap, dan berperilaku itu singkron dan satu.

Akhlak adalah missi utama dari risalah Islamiyah, kerasulan Muhammad SAW. ${ }^{24}$ Maka selaku umat M uhammad, umat Islam melihat, memang semestinya jika akhlak menjadi kesadaran hidup beragama.Sebagaimana halnya iman dan ibadah, umat Islam melihat akhlak juga mesti ditanamkan sejak dini. M eski demikian, pada kenyatannya, perhatian mengenai akhlak barulah secara awam, sehingga kedalaman, keluasan, dan ketinggian dari apa yang disebut akhlak sebenarnya masih menjadi misteri di kalangan umat Muhammad hingga kini.

Sebagai 'ajaran' dari agama, akhlak sudah tentu 'harus' diamalkan bagi yang mengakui agamanya, atau jika tidak, pasti akan dinilai tidak berakhlak, bahkan menyalahi agamanya. Akhlak itu kualitas perbuatan manusia, maka bisa jadi orang telah berbuat, atau bahkan telah berbuat banyak, namun secara kualitas, akan ditentukan oleh akhlaknya, dalam arti, akan dinilai berkualitas jika didasari dengan akhlak. Banyak orang menjalani hidup, bahkan melayarinya sampai jauh entah kemana, tapi tidak sedikit yang tidak merasakan makna hidup, hanya karena tidak mendasari hidupnya dengan akhlak. M aka akhlak juga bisa dimengerti sebagai "makna" dari kehidupan ini, yang menjadi tangga untuk peningkatan kedewasaan hidup. Lebih dalam lagi, akhlak itu adalah wujud eksistensi manusia, sebab dengan akhlak, 


\section{4. жrawu}

manusia menjadi berada, menjadi wujud, dan sebaliknya tanpa akhlak, adanya dianggap tidak ada, wujuduhu ka 'adamihi, baik di hadapan manusia, maupun lebih-lebih di hadapan Tuhan. ${ }^{25}$

Secara lebih praktis, akhlak itu berbuat berdasarkan aturan, atau bahkan peraturan (termasuk pasal-pasal, undang-undang, dst.), atau jika dilihat dari sisi pelaku, berarti berbuat berdasarkan pertimbangan logis dan realistis. Maka perbuatan yang dilakukan tanpa pertimbangan logis dan realistis, dan tanpa aturan, meskipun secara maksud dan tujuan dinilai baik, tetap tidak masuk dalam kategori akhlak, apalagi jika maksud dan tujuannya memang salah. Sebaliknya bahkan perbuatan memperturut keinginan nafsu, jika dengan pertimbangan logis dan realistis, dan pakai aturan, itu menjadi sah dan terhormat. Meski demikian perlu dicatat, bahwa peraturan 'yang logis dan realistis' itu mesti dibangun di atas nilainilai etis dan mengandung pesan moral, sehingga melaksanakan peraturan, belum dinilai sebagai perbuatan berakhlak sebelum ditemukan nilai etis dan pesan moralnya. Selanjutnya jika dalam pelaksanaan peraturan ditemukan hal-hal yang bertentangan dengan nilai etis dan moral, maka peraturan harus disesuaikan, sudah tentu, juga dengan cara-cara yang etis, jadi bukan nilai etisnya yang diubah. Nilai-nilai etis dalam akhlak itu dibangun bukan tanpa orientasi, sebab bagaimanapun nilai-nilai etis itu bersumber pada tata nilai yang lebih tinggi yaitu tatanilai ketuhanan. ${ }^{26}$ M aka kesadaran etis dalam menjalani hidup beraturan, juga dalam kerangka taat dan taqwa pada Tuhan. Inilah bangunan akhlak secara sistemik.j ika pemikiran itu dibalik, maka wujud taat dan taqwa pada Tuhan itu adalah hidupnya kesadaran menjunjung tinggi nilai-nilai etis dan diwujudkan dengan perbuatan berdasarkan hukum dan mengikuti tataaturan. Pola kesadaran akhlak secara skematik bisa dilihat pada Gambar 1.

Keterpisahan atau apalagi kekaburan mengenai 'lapis-lapis' kesadaran akhlak ini menimbulkan perbuatan umat beragama menjadi sempit dan kabur juga. Ada sebagian yang sibuk bertanya persoalan hukum, menjalani dan menerapkan hukum-hukum, tetapi jusru abai terhadap nilai-nilai etis dan pesan-pesan moral yang mendasarinya, bahkan hingga tidak ditemukan sambungannya dengan tata nilai ketuhanan seperti ketakwaan dan ketaatan. ${ }^{27}$ Pada sisi yang lain, ada yang merasa taat dan takwa pada tuhan, tetapi abai terhadap peraturan dan hukum-hukum, dan tidak menyadari apa nilai etis dan pesan moral yang dapat digali dari ketaatan dan ketakwaannya. 


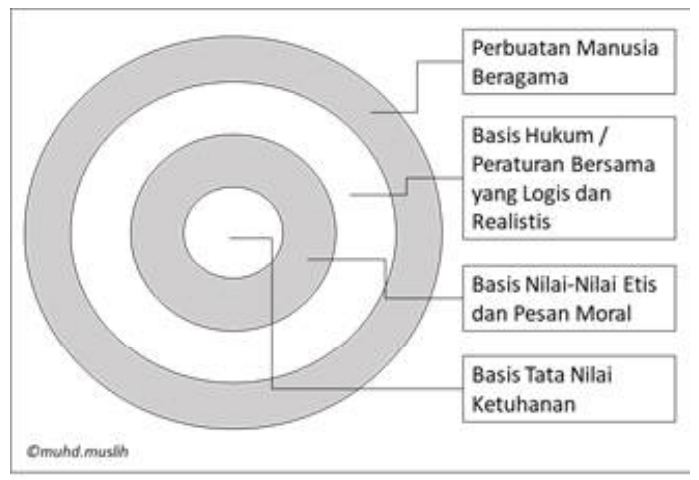

Gambar 1: Pola Kesadaran Akhlak

Persoalan lain yang sering berkembang di masyarakat, mengapa harus mengikuti peraturan dan hukum-perundangan yang nyata-nyata bikinan manusia, bukankah selaku hamba Allah, manusia harus menjalani hanya aturan-Nya. Di sini, dapat disampaikan, aturan memang harus dariNya, tapi peraturan boleh dari 'anda' atau dari 'mereka', atau dari 'kita'. Peraturan itu pem-bahasa-an, atau lebih tepatnya perumusan tataaturan dalam bentuk bahasa dari aturan Tuhan, yang mungkin bisa diterima oleh masyarakat manusia, mulai dari kelompok kecil, hingga kelompok besar.Disebut bahwa aturan itu dari Tuhan, pengertiannya adalah bahwa aturan itu benar-benar steril dari ego pribadi, mau-mau golongan, kepentingan pragmatis, terlebih lagi yang dipaksakan atas namaNya. Karena memang hanya sekedar dari 'anda', 'mereka' atau dari 'kita', bisa jadi peraturan itu tidak sejalan atau malah bertentangan dengan aturanaturanNya, meskipun juga tidak selamanya atau tidak harus terus seperti itu. Maka sudah semestinya yang namanya peraturan itu diterima, selama sejalan dengan aturanNya, atau selama tidak bertentangan dengan aturanNya. Pemandangan yang sangat ganjil di masyarakat, orang yang merasa agamis, rata-rata malah sengaja tidak meng indahkan hukum (perundang-undangan), dan malah hidup dan berjalan dengan hukum sendiri yang katanya hukum agama itu. Padahal dunia ini sedang menunggu, keteladanan mereka dalam hal mentaati hukum, dan dalam hal mengembangkan bangsa dan negara menjadi beradab.

Dengan kerangka berpikir seperti ini, membawa pembicaraan akhlak tidak saja dalam konteks perbuatan baik oleh individu-individu, tetapi dalam konteks hidup bersama, secara sistemik, kolektif, kultural. Dalam 


\section{6 | м⿻а木w}

arti, membawa manusia untuk hidup berdasarkan sistem yang berlaku di lingkungan dan masyarakatnya, menahan kediriannya, mengedepankan keamanan dan kenyamanan bersama dalam keindahan budaya. Jika ambisi, egoisme, fanatisme, sentimen kesukuan, kedaerahan, kemadzhaban, masih dominan memenuhi ruang publik, berarti terjadi perbuatan unsystem, maka menjadi mustahil terbangun masyarakat etis, agama etis, kampus etis, ilmuwan etis, dst. Maka agar akhlak dapat diaplikasikan atau agar kehidupan etis dapat dijalani, sistem harus ada dan dibangun. M eski begitu tetap dengan kesadaran bahwa sistem masih mungkin bisa dikembangkan, bahkan harus dikembangkan, tapi mesti secara landai dan berkala, agar tidak timbul kegaduhan, agar tidak terjadi instabilitas sosial. Sistem, dengan demikian, merupakan sisi luar dari akhlak, maka keduanya mesti selaras. Jika ternyata ditemukan ketidakselarasan, sistem mesti bisa diperbaiki, bukan sebaliknya.Selain itu, sistem juga bisa dimengerti sebagai wujud terlaksananya akhlak, sebab kemuliaan akhlak terlihat dari keberjalanan sistem.

Terkait dengan pengembangan ilmu, sudah tentu etos kerja (ilmiah) dari individu-individu memiliki peran yang sangat penting, tetapi tidak bisa diharapkan bisa bertahan, jika tidak didukung oleh sistem, tradisi, dan budaya ilmiah. Bahkan kerja ilmiah itu sangat dapat berkontribusi terhadap pengembangan sistem, tradisi, dan budaya ilmiah itu sendiri, sebaliknya, sistem juga bisa membangkitkan etos kerja (ilmiah) individuindividu sebagai bagian dari komunitas ilmiah. Itu artinya, pengembangan ilmu bukan hanya singkron dengan akhlak, tetapi bahkan pengembangan ilmu baru dapat berkembang hanya dengan dukungan akhlak dalam bentuk sistem, tradisi, dan budaya ilmiah. Sebagai konsekuensi dari pandangan demikian, maka jika kerja ilmiah sudah dilakukan dengan tingkat keilmiahan yang tinggi, profesional, dan penuh tanggungjawab, maka tidak perlu dipertanyakan di mana akhlak, sebab itu sudah merupakan bentuk pelaksanaan akhlak dalam kaitannya dengan kerja ilmiah.

\section{Nalar D akwah}

Cukup kuat pandangan masyarakat muslim bahwa Islam adalah agama dakwah.kesimpulan semacam itu sudah tentu dapat dengan mudah ditemukan dasar normatif berupa dalil al-Qur'an dan hadits, maupun dasar historisnya sepanjang perjalanan dakwah Rasul dan Shahabat, sehingga sangat wajar jika kemudian menjadi kesadaran umum masyarakat mu- 
slim. ${ }^{28} \mathrm{Namun}$, tidak dapat dipungkiri beberapa persoalan kemudian muncul menyertai pandangan umum itu, yaitu ketika aktivitas dakwah dinilai tidak sejalan dengan aktivitas ilmiah, begitu juga, dengan pandangan bahwa kerja ilmiah itu tidak memiliki unsur dakwah. Panda-ngan demikian, pada awalnya terjadi dan mengental pada masyarakat kampus, dan ini yang istimewa. Namun karena terus disuarakan dan suaranya terdengar cukup keras, bahkan terus digulirkan, sudah tentu persoalannya lalu menjadi begitu menggelisahkan dan tidak mudah untuk diluruskan.

Dalam masyarakat muslim dan tradisi islam pada umumnya, kata dakwah, baik sebagai konsep maupun aktivitas, sering diidentikkan dengan pendidikan (tarbiyah), dengan alasan di dalam dakwah ada unsur pendidikan, dan di dalam pendidikan ada unsur dakwah, apalagi dalam praktiknya kedua aktivitas itu memang tidak mengenal usia. Antara dakwah dan pendidikan sudah tentu merupakan aktivitas penting bagi kehidupan, sekaligus sama-sama merupakan ajaran penting dalam agama Islam.M eski demikian, karena yang satu dengan yang lain tidak ada pemilahan wilayah yang jelas, terutama pada konsepnya, maka aktivitas keduanya pada kenyataannya menjadi tidak maksimal.

Secara konseptual, dakwah dan tarbiyah itu mestinya tidak terpisah, keduanya mestinya dapat berjalan seiring, meskipun tetap harus dibedakan, karena memiliki wilayah 'garapan' masing-masing. Secara sederhana, dapat disebut bahwa tarbiyah itu garapannya pada wilayah "basic", sementara dakwah, garapannya pada wilayah lanjutan. Sejalan dengan garapannya yang berada pada wilayah "basic", tarbiyah pada intinya, menyiapkan manusia, atau membuat manusia menjadi siap, baik secara fisik, psikis, mental, dan akal pikirannya, untuk memasuki masa-masa produktif. Maka sebenarnya belum dianggap selesai proses pendidikan, jika orang dinilai belum cukup siap memasuki masa-masa produktifnya. Demikian pula, pendidikan belum dapat dinilai berhasil jika orang ternyata tidak siap memasuki masa-masa produktif. Di sini disebut masa, bukan usia, sebab pendidikan memang tidak mengenal usia, makanya ada adult education..$^{29}$ M eskipun, tetap akan menjadi salah kaprah, jika ada orang yang semestinya sudah cukup siap memasuki masa produktif, tetapi kondisinya masih belum beranjak dari pendidikan.Sudah tentu ini merupakan kesalahan hidup.

Jika dapat diibaratkan dengan sebuah anak tangga misalnya, maka pendidikan itu berada pada anak tangga yang paling bawah. Meskipun 


\section{$208 \mid$ нerum}

perlu ditegaskan, berada pada wilayah 'basic' atau pada anak tangga dasar, bukan berarti pendidikan merupakan persoalan sepele, simpel, atau sederhana.Sebaliknya pendidikan merupakan bagian dari hidup manusia yang penting, dan pada tahap ini potensi 'terpendam' manusia mesti digali dan ditumbuh-kembangkannya untuk menjadi karakter yang kuat. Maka di situlah arti penting dan peran strategis pendidikan dapat diposisikan.

Setelah pendidikan menyelesaikan perannya pada tahapan perkembangan manusia, mestinya untuk selanjutnya dakwah mulai berperan.W ilayah garapan dakwah adalah manusia yang telah siap memasuki masa-masa produktif, dan tentu saja mereka sudah selesai dengan masa persiapannya. Dengan begitu, tidak salah jika disimpulkan, bahwa dakwah itu sasarannya adalah orang-orang yang secara usia lebih dewasa. Berbeda dengan pendidikan yang segala potensi, kemampuan, dan talenta, masih dalam proses dilatih, ditumbuh-kembangkan, pada dakwah, segala talenta, kreativitas, dan kemampuan (bertahan, menjelajah, beradaptasi, dan lainnya) itu sudah harus siap jalan dan beraksi.

Dalam praktiknya, dakwah itu dapat berupa aktivitas tertentu, program tertentu, dapat juga dalam bentuk yang sebenarnya atau yang artifisial, dapat berupa ucapan atau tulisan, perbuatan atau sikap, dan lain-lain, yang dapat mengantarkan seseorang, komunitas, masyarakat, tradisi dan budaya, bahkan suatu bangsa, untuk mencapai kesuksesan hidup. ${ }^{30}$ Semua bentuk-bentuk aktivitas dakwah itu dilakukan sesuai dengan posisi, keahlian, kemampuan (subyektif dan obyektif), profesi, dan sarana yang ada. Maka orang tua, teman, saudara, tokoh agama, tokoh masyarakat, kolega, pemimpin, segenap profesional, atau siapapun, dapat dinilai menjalankan aktivitas dakwah jika dengan aktivitasnya itu membantu mengantarkan siapapun (sasaran dakwah) mencapai kesuksesan hidup atau membuat hidup sukses lebih sukses lagi.

Dengan kerangka pikir seperti itu, menjadi sangat jelas bahwa mestinya tidak tepat da'i disebut sebagai suatu profesi, begitu pula sebutan lembaga dakwah mestinya juga tidak ada, dan sudah menjadi salah kaprah juga, sebutan (laqab) da'i untuk para "penceramah agama". Sebab, dari sisi profesi, aktivitas dakwah tidak lain adalah aktivitas profesional dari profesi apapun. Jika seorang profesional diharapkan untuk bisa sambil berdakwah, berarti dengan posisi dan kapasitasnya, dia diharapkan perannya dalam ikut membantu orang lain dalam meraih kesuksesan atau meningkatkan kesuksesan hidupnya menjadi lebih sukses lagi. 
Dengan tetap menyadari banya cukup banyak teori, model, dan strategi dakwah, namun dalam kajian ini hanya akan mengungkap satu hal, yang sebenamya merupakan elemen penting, namun sering terlewat dari aktivitas dakwah, yaitu terkait hajat dasar hidup manusia. Secara sederhana apa yang disebut hajat dasar terdiri dari tiga tahapan, yaitu: pemenuhan kebutuhan dasar hidup, pemantapan eksistensi, dan perwujudan kesadaran partisipatif. ${ }^{31}$ Berkaitan dengan tiga tahapan hajat dasar tersebut, maka secara konseptual, dakwah juga dapat wujudkan dalam tiga tahapan, yaitu dapat disebut: 1). Sukses pemenuhan kebutuhan dasar, 2). Sukses pemantapan eksistensi, dan 3). Sukses perwujudan kesadaran partisipatif.

Pertama, sukses pemenuhan kebutuhan dasar, yang meliputi kebutuhan pakaian, makan, tempat tinggal, dan pasangan (baca: menikah). ${ }^{32}$ Pada tahap pertama ini dakwah merupakan usaha untuk membuka "ruang gerak" untuk berkembangnya kreativitas dan produktivitas, juga menumbuhkan kemampuan bertahan atas segala rintangan hidup, dan menghindari kegagalan dalam menjalani ujian hidup. ${ }^{33}$ Pada masa-masa pemenuhan kebutuhan dasar ini, menjadi wajar, makanya dapat dimaklumi, jika pada diri seseorang atau komunitas, organisasi, tradisi dan budaya, bahkan suatu bangsa (dalam hal ini, subjek dakwah), ada sikap individualis, agresif, berani, tidak memikir yang lain (the other), dan lain-lain. Sikapsikap seperti ini, pada taraf tertentu, tetap penting dipertahankan dan bahkan perlu untuk ditumbuh-kembangkan, sebab tidak mungkin ada upaya memenuhi kebutuhan dasar, jika yang ada hanya sikap pasrah, takut, dan pesimis, umpamanya. M eskipun tetap dengan catatan, jangan sampai berlajut menimbulkan sikap resisten, dusta, curang, persaingan tidak fair, permusuhan, dan apalagi pertengkaran. Dengan adanya sikap-sikap yang menyertai masa pemenuhan kebutuhan dasar seperti disebutkan itu, maka akan sulit diharapkan dapat tumbuh sikap empati, tenggang rasa, dan kepekaan sosial. Oleh karena itu, jika aktivitas yang disebut dakwah itu mengusung tema-tema ini, dijamin tidak akan berhasil, karena memang kondisi subjek dakwah masih belum selesai dengan pemenuhan kebutuhan dasarnya.

Kedua, sukses proses pemantapan eksistensi.Secara sederhana, dakwah pada tahap kedua ini lebih sebagi usaha menumbuhkan sikap empati, simpati, kepekaan sosial, trust, berpikir kebaikan bersama, berpikir kebaikan lingkungan, orientasi jangka panjang, dan seterusnya. Beberapa hal itu, terkait hajat dasar manusia dalam hal eksistensi. Hajat dasar ini yang 


\section{$210 \mid$ seavus}

meniscayakan manusia untuk menemukan kebermaknaan dirinya di tengah-tengah kehidupan masyarakat, lingkungan sosial, serta tradisi dan budayanya. ${ }^{34}$ Tingkat keberhasilan dakwah pada tahap ini, ditandai dengan tumbuhnya sikap berkorban tanpa pamrih, bukan hanya menjadi orang baik tetapi membaikkan lingkungan masyarakatnya, bukan hanya lingkungannya merasakan kebaikannya, tetapi lingkungannya menjadi baik sebab keberadaannya. Inilah yang dimaksud dengan eksistensi, yang mana lingkungan dan masyarakatnya telah menempatkan keberadaannya sebagai sosok yang penting karena kebaikan-kebaikannya. Pencapaian seperti ini dimungkinkan dapat terwujud karena subjek dakwah sudah "selesai" dengan kebutuhan dasarnya. Sebaliknya, jika kebutuhan dasar memang belum terpenuhi, apalagi masih kekurangan, maka kerja sosial, kerja lingkungan, akan sulit diharapkan dapat dilakukan dengan tanpa pamrih atau tanpa maksud pribadi terselubung. Maka yang tepat,untuk subjek dakwah yang masih belum selesai dengan pemenuhan kebutuhan dasarnya, sebenarnya tidak perlu sampai diharap seperti itu, bahkan mestinya, pamrih-pamrih dan maksud-maksud terselubung itu aktivitas dakwah berhasil menemukan jalan pemenuhannya.

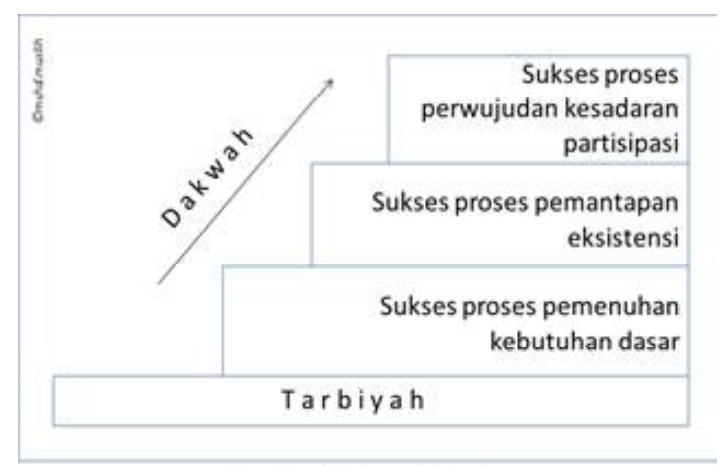

Gambar 2: Tahapan Dakwah

Ketiga, tahap sukses perwujudan kesadaran partisipatif. Pada tahap ini, aktivitas dakwah diselenggarakan dengan asumsi bahwa subjek dakwah sudah selesai dengan kebutuhan sandang, pangan, papan, dan pasangan, dan sudah tidak butuh pengakuan, apalagi sampai gila hormat, sebab eksistensinya memang sudah begitu terasa. Oleh karena itu tema dakwah sudah tidak lagi berkenaan dengan kepekaan sosial, apalagi kerja untuk pemenuhan kebutuhan dasar, tetapi lebih kepada menumbuhkan 
"kesadaran kritis" sasaran dakwah. Tujuan akhirnya adalah lahir hasrat kuat dalam bentuk program-program kreatif dalam ikut serta mengangkat harkat martabat kemanusiaan, terlibat aktif dalam mewujudkan nilai kemanusiaan, mengutamakan kemaslahatan universal dan perdamaian dunia.Ini semua dilakukan dengan tingkat kearifan dan kebijaksanaan yang tinggi. Tiga tahapan dakwah dan kaitannya dengan pendidikan itu dapat ditunjukkan secara lebih sederhana pada Gambar 2.

Antara tarbiyah dan dakwah berikut tahapan-tahapannya seperti diuraikan di atas, sudah tentu tidak bersifat clear cut, dalam arti secara realitasnya benar terpisah antara satu tahapan ke tahapan berikutnya, akan tetapi dengan tidak mempertimbangkan tahapan-tahapannya, aktivitas yang kemudian disebut dakwah itu akan sulit untuk berhasil, atau akan mengalami kegagalan, dan sangat mungkin malah kontraproduktif. Dengan karangka pemikiran (conceptual framework) seperti diuraikan di atas, maka peneliti dan ilmuwan, guru dan dosen, termasuk pelajar dan mahasiswa, justru dimungkinkan dapat mengambil peran lebih banyak, dengan ilmu pengetahuan yang dimiliki, juga pelajaran dan pengalamannya. Dalam konteks pengembangan sains, sukses pemenuhan hajat dasar manusia yang dilakukan dalam bentuk tiga tahapan dakwah pada dasarnya merupakan orientasi dan tujuan utama dari sains, bahkan secara keseluruhan aktivitas ilmiah adalah dakwah. Sedangkan dalam konteks dakwah, aktivitas ilmiah sudah dengan sendirinya akan mengantarkan manusia untuk meraih sukses hidup sebagaimana dimaksudkan oleh dakwah. Dengan demikian, antara aktivitas ilmiah dan dakwah ternyata dapat bertemu, bahkan kerja sains sekaligus merupakan aktivitas dakwah juga.

\section{PENGEM BANGAN SAINS DALAM KONTEKS INTEGRASI ILMU AGAMA DAN ILMU UMUM}

Istilah "IImu Agama" adalah gabungan kata "ilmu" dan kata "agama". Meski istilah ilmu agama sudah sedemikian populer, tetapi tetap terkesan sebagai dua kata yang dipaksa dijodohkan, atau bahkan terkesan tidak berjodoh. Sebab, sejauh ini, kata agama lebih cocok dengan kata ajaran, yaitu "ajaran agama", sementara kata ilmu serasinya dengan kata alam, sosial, bahasa, kesehatan, dan lain-lain, sehingga ada ilmu alam, ilmu sosial, ilmu bahasa, ilmu kesehatan, dan lain-lain. Jikalau ada proses transisi atau transformasi berupa pengembangan dari agama sebagai ajaran ke agama sebagai ilmu, nyatanya sampai hari ini berjalan lambat, untuk tidak 


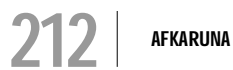

mengatakan tidak beranjak, atau malah tidak berhasil, sehingga sekalipun sudah disebut "ilmu agama" masih sangat berasa "ajaran agama". Hal ini menjadi semakin jelas jika melihat pada sosok mereka yang menggeluti bidang ilmu agama (sarjana agama, dan semacamnya), mereka lebih comfy, lebih enjoyable sebagai sosok 'pengajar agama' daripada sebagai 'ilmuwan agama'. Demikian juga institusi di segala tingkatan, bahkan lembaga riset, kalau berbasis ilmu agama, atau di lingkungan lembaga keagamaan, semuanya masih belum bisa keluar dari bayang-bayang agama sebagai ajaran. ${ }^{35}$

Dalam tradisi keilmuan Islam, apa yang disebut ilmu agama ('ulum aldin) adalah ilmu yang menjadikan sumber-sumber keagamaan sebagai 'objek' kajiannya, yaitu nash Al-Qur'an dan sunnah Rasul. Hal ini sudah tentu berbeda dengan sains yang mempelajari fenomena empiris. Dalam prosesnya, sumber-sumber keagamaan itu dikaji dalam berbagai aspeknya. Upaya ini dalam rangka menggapai maksud dari sumber tersebut. Sejauh ini, perangkat metode pengambilan hukum (istinbath) dari kedua sumber tersebut, bisa disebut sejumlah istilah, yaitu ijtihad, qiyas, istidlal, istintaj, tafsir dan ta'wil.Sudah tentu beberapa perangkat metode ini memiliki kekhasannya masing-masing, dan karenanya ilmu yang dihasilkannya berbeda-beda pula.

Karena metodenya yang khas dan objeknya yang istimewa, memang tidak sembarang orang mempunyai kemampuan, bahkan mempunyai hak untuk mengkajinya. Ada sejumlah syarat yang harus dimiliki seseorang untuk dapat melakukan kajian terhadap objek ini, apalagi untuk dapat menghasilkan suatu produk 'hukum' ilmu agama. Maka dalam hal ini, ada dibenarkan seseorang sekedar mengikuti (ittiba' atau taqlid) pendapat yang sudah ada. Sepanjang sejarah Islam, ada banyak ragam khazanah keilmuan, baik dalam kelompok ushul maupun furu', misalnya IImu Figh, IImu Kalam, Filsafat Islam, IImu Tasawuf, 'Ulum al-Quran, 'Ulum al-Hadits, dII. Beberapa ilmu yang termasuk dalam rumpun dirasah islamiyah atau islamic studies ini juga terus dikembangkan hingga hari ini.

Di kalangan ahli ilmu-ilmu keislaman, belakangan ini muncul trend, dan semangat kuat untuk mengembangkan integrasi ilmu sebagai 'proyek' besar keilmuan. Untuk proyek ini, memang ada dua trend, yang pertama, memanfaatkan temuan-temuan sains dan metodologi saintifik untuk pengembangan ilmu-ilmu keislaman, dan kedua, mengintegrasikan ilmu keislaman yang masuk dalam rumpun dirasah islamiyah itu dengan apa 
yang disebut dengan ilmu 'umum', yang secara lebih riel, aplikasinya adalah mendasarkan, memasukkan, dan mewarnakan ilmu-keislaman kepada ilmu-ilmu 'umum'. Upaya ini dimaksudkan sebagai tahapan awal dari proyek Islamisasi ilmu. ${ }^{36}$ Pembahasan ini tidak dimaksudkan untuk mengkaji tentang apa alasan, dan bagaimana program pengembangan dari dua trend itu. Poin kajian ini adalah bahwa prinsip dasar mempertemukan dua atau lebih entitas adalah perhatian tertuju pada segi positifnya, dan dilakukan tidak untuk menang-kalah, artinya jika perhatian pada sebaliknya, misalnya hanya negatifnya yang dilihat, atau agar yang lain kalah, untuk apa ada pertemuan, dan untuk apa dipertemukan, karena pada dasarnya sudah jelas tidak akan bisa ketemu. Integrasi keilmuan, pada kenyataannya (penulis tidak tahu pada konsepnya) masih belum berpegangan pada prinsip dasar itu, maka itu suatu 'proyek' berat, kecuali yang satu dapat mengalah legowo karena lebih dewasa. Kalau yang jadi perhatian hanya sisi negatifnya dan untuk menundukkannya, bahkan persahabatan dan perkawinanpun, mustahil terjadi.

Sebenarnya setiap ilmu itu mempunyai corak, karakteristik, dan logika sendiri-sendiri, namun meski begitu, masing-masing ilmu tidak sulit untuk bertemu atau dipertemukan jalinannya, maka pertemuan antar ilmu, atau ilmu-ilmu sangat mungkin terjadi, selama itu memang benar-benar ilmu, apapun nama ilmunya. Pertemuan ilmu-ilmu itu kemudian disebut interdisipliner dan multidisipliner. Maka ini hal biasa bagi ilmu dan ilmuwan, sehingga harus diakui itu sebenarnya bukan 'proyek' luarbiasa sebagaimana dihebohkan belakangan ini. Mestinya juga tidak perlu muncul kekhawatiran, apalagi penolakan, sebagaimana selama ini sering dialamatkan pada proyek integrasi keilmuan.

Ilmu-ilmu, seperti sosiologi, antropologi, psikologi, sejarah, memang ilmu-ilmu yang tergolong modern, sudah tentu para mutakallim, para fuqaha, para mufassir tempo doeloe belum mengenal ilmu-ilmu itu, tapi tidak betul jika dikatakan bahwa mereka itu tidak memiliki, dan tidak memakai nalar (termasuk sensitivitas dan taste) sosiologis, antropologis, psikologis, historis dalam kerja ilmiah mereka. Kalau ilmu-ilmu tersebut, dan ilmu-ilmu yang tergolong natural siciences, dewasa ini kemudian diupayakan diintegrasikan dengan ilmu-ilmu keislaman, itu berarti untuk membangunkan nalar-nalar itu atau untuk memanfaat temuan-temuannya, bukan sebagai upaya liberalisasi ilmu-ilmu keislaman, apalagi disebut sebagai bentuk infiltrasi ilmu 'umum' ke dalam ilmu-ilmu keislaman. 


\section{4. * жrawu}

Dengan integrasi keilmuan, bisa jadi, ilmu-ilmu yang disebut ilmu umum itu akan mengalami kemajuan juga, meski awalnya merasa dipaksa kawin paksa dengan ilmu agama, tapi juga bisa sebaliknya, ilmu-ilmu yang disebut ilmu agama itu akan stagnan tidak ada perkembangan, dan cenderung ketinggalan jaman, kalau engganmemberi tempat yang layak untuk ilmuilmu umum di sisinya, apalagi kalau selalu mencurigai hadirnya.

\section{PENUTUP}

Ketertinggalan di bidang sains dan teknologi memang suatu persoalan besar dalam hidup, tetapi jika ketertinggalan itu disebut bukan urusan agama, apalagi jika dipahami agama tidak berururan dengan pengembangan sains dan teknologi, maka itu kesalahan terbesar dalam menjalani agama. Akan tetapi, tidak hanya kalangan agamawan dan umat beragama pada umumnya, tetapi hingga para sainstis, melihat bahwa pengembangan sains itu hanyalah urusan keilmuan semata, yang hanya berkaitan dengan persoalan teori, metodologi, atau paling tidak urusan fisafat ilmu dan epistemologi, padahal pengembangan ilmu itu tidak dilepaskan dari konteks sosial dan bahkan konteks agama. Sehingga pengembangan ilmu bukan hanya problem keilmuan semata, tetapi juga problem kemasyarakatan dan problem keislaman, terkait pola pemahaman masyarakat dan umat beragama mengenai apa itu ilmu dan apa itu agama. Maka membangun pola kesadaran keislaman baru mesti terus dilakukan, agar pengembangan ilmu berjalan maksimal dengan tanpa menimbulkan masalah sosial, sebab sudah dapat diletakkan pada konteksnya yang benar, yaitu konteks agama.

\section{CATATAN AKHIR}

1 Lihat W ebster's $\mathrm{N}$ ew World D ictionary of the A merican L anguage, (Cleveland and New York: The World Publishing Company, 1962), h.1305.

2 Mulyadhi K artanegara, M enyibak Tirai K ejahilan, Pengantar E pistemologi Islam, (Bandung: Mizan, 2003), h. 1.

3 Lihat Mohammad M uslih, Logika K etuhanan dalam E pistemologi illuminasi Suhrawardi, (Yogyakarta: Lesfi, 2014).

4 M enurut Jujun S. Suriasumantri, knowledge merupakan terminology generic, dan science adalah anggota (species) dari kelompok (genus) tersebut. Jujun S. Suriasumantri, Filsafat IImu Sebuah Pengantar Populer. (Jakarta: Sinar H arapan, 1990), h. 294.

5 Yang dalam terminologi ilmu logika disebut abstraksi (altajrid) atau proses immaterialisasi. Lihat W. Poespoprojo, L ogika Scientifika, Pengantar D ialektika 
dan IImu, (Bandung: Pustaka G rafika, 1999), h. 69.

6 Steven Burgess, "N ietzsche and $\mathrm{H}$ eidegger on the $\mathrm{C}$ artesian Atomism of Thought" Dissertation (U SA: U niversity of South Florida, 2013), h. 66.

7 Simon PetrusL Tjahjadi, Tuhan Para Filsuf dan IImuwan, (Yogyakarta: Kanisius, 2007), h. 28-36.

8 G.W.F. Leibniz, "The M onadology," in The Rationalists, trans. George M ontgomery, (New York: Doubleday, 1960), h. 455-71.

9 Disebutkan: "U Itimately, W olff believes that the Principle of C ontradiction, the Principle of Sufficient Reason, and the Principle of C onceptual Implication (or Principle of the Syllogism) are all innate to the human mind." Lihat http:/ / plato.stanford.edu/ entries/ wolff-christian/ diakses pada Selasa 26 Juli 2016 jam 03.35.

$10 \mathrm{H}$ arun H adiwiyono, Sari Sejarah Filsafat Barat 2, (Yogyakarta: Kanisius, 1980), h. 33

11 Henry E. Allison, C ustom and Reason in $\mathrm{H}$ ume, $\mathrm{A}$ K antian Reading of the First Book of the Treatise, (O xford: O xford U niversity Press, 2008). Buku ini telah direview oleh Paul Guyer, Book Reviews "C ustom and Reason in H ume, A Kantian Reading of the First Book of the Treatise" dalam H ume Studies, Volume 35, Number 1,2 (2009), pp. 236-239.

12 Ini maksud David H ume dengan idea. Lihat Shane D refcinski, "A Very Brief Summary of David Hume", dalam http:/ / people.uwplatt.edu/ drefcins/ humeencyclopediaentry.html diakses Selasa, 26 Juli 2016 jam 05.00.

13 Yang dalam kajian filsafat, diajukan oleh aliran Empirisisme, sebagaimana disebutkan: "Empiricism is a theory that states that knowledge comes only or primarily from sensory experience". Lihat StathisPsillos and M artin C urd, The Routledge Companion to Philosophy of Science (1. publ. in paperback ed.), (London: Routledge, 2010), h. 129-138.

14 A ktivitas berpikir inilah yang secara tradisional dibahas panjang lebar dalam ilmu logika, dan secara lebih khusus dalam kaitannya dengan proses terbentuknya pengetahuan, kajian filsafat modern mengupasnya dalam aliranaliran epistemologi sebagai cabang Filsafat yang membicarakan teori pengetahuan. Lihat Noah Porter, ed., "E pistemology". W ebster's Revised Unabridged Dictionary, (G \& C. M erriam Co 1913), h. 501.

15 Lihat Imre Lakatos, The M ethodology of Scientific Research Programmes, (C ambridge: C ambridge U niversity Press, 1995),h. 8-9

16 Holmes Rolston, III, Science and Religion: A C ritical Survey, (N ew York: Random H ouse, Inc., 1987), h. vii

17 Dalam hal ini, Rolston menulis: "It needs to keep its autonomous integrity and resilience." Lihat ibid.

18 Lihat: M. A min Abdullah, Islamic Studies di Perguruan Tinggi: Pendekatan Integratifinterkonektif, (Yogyakarta: Pustaka Pelajar, 2006), h. 399-405.

19 Dalam satu artikelnya, Prof. Amin Abdullah menulis: "Ciri fundamental budaya I slam adalah ketergantungannya yang sangat kuat terhadap nash atau text," Lihat M . A min A bdullah, "Kontribusi IImu Kalam/Filsafat Islam dalam 
Pembangunan Karakter bangsa", IImu U shuluddin, Volume 13, Nomor 2, Juli 2014, h. 99.

20 Dari I bnu M as'ud ra. berkata, R asulullah Saw bersabda, "Bukanlah seorang mukmin orang yang suka mencela, orang yang gemar melaknat, orang yang suka berbuat/ berkatakata keji dan orang yang berkata-kata kotor/ jorok". (H R at-Turmudziy, al-Bukhariy, A hmad, dan al-H akim). Lihat Shahih Sunan at-Turmudziy: 1610, Shahih al-Adab al-Mufrad: 237, Shahih al-Jami' ashShaghir: 5381 dan Silsilah al-A hadits ash-Shahihah: 320

21 Lihat QS. Al-M ujadilah [58]: 11.

22 Lihat Q S. Al-D zariyat [51]: 56 (D an tidaklah A ku ciptakan jin dan manusia kecuali untuk beribadah kepada-Ku")

23 Ini dapat digali dari ayat:"Katakan, sesungguhnya shalatku, manasikku, hidupku dan matiku hanya demi Allah Tuhan semesta alam. Tidak ada sekutu bagi-N ya, dan demikianlah yang diperintahkan kepadaku dan aku adalah orang yang pertama-tama berserah diri." (Q S. al-An'am [6]: 162-163).

$24 \mathrm{H}$ adits tentang akhlak yang paling terkenal; "innama buitstu liutammima makarimal akhlaq" diriwayatkan al-Baihaqi oleh A bu H urairah dalam Sunan Baihaqi nomor 20571

25 Sebagaimana petunjuk Q S.al-Baqarah [2]: 112 ((Tidak demikian) bahkan barangsiapa yang menyerahkan diri kepada Allah, sedang ia berbuat kebajikan, maka baginya pahala pada sisi Tuhannya dan tidak ada kekhawatiran terhadap mereka dan tidak (pula) mereka bersedih hati).

26 Itulah sebabnya dalam hukum Islam, dalam melakukan perbuatan hukum, mukallaf disyarakatkan mengerti hukum taklif, sekaligus mashlahah yang menjadi tujuan dilakukannya. Dalam kajian M aqâsîd al-sharî'ah dari sisi shâri' (pembuat hukum) disebutkan ada empat aspek, yaitu tujuan syariah adalah untuk kemaslahatan, syariah sebagai sesuatu yang harus dipahami, syariah sebagai hukum taklîf yang harus dilakukan, dan tujuan syariah adalah untuk membawa manusia ke bawah naungan hukum, maka perbuatan etis atau berakhlak itu adalah berbuat berdasarkan hukum. Lihat A bû Ishâq al-Shâthiby, al-M uwâfaqât min U sûl al-Sharî'ah, (Kairo: M usthafâ M uhammad, tth), h. 5

27 Sekedar untuk perbandingan, dalam konteks Barat, apa yang menjadi kegelisahan Friedrich $\mathrm{N}$ ietzsche tentang matinya tuhan dalam keberagamaan kristiani, adalah karena beragama hanya berhenti pada lapis hukum dan peraturan, tapi tidak menyentuh soal nilai etis dan tatanilai ketuhanan. Lihat St. Sunardi, N ietzsche, (Yogyakarta: LKiS, 2011), h. 143-147

28 M isalnya seperti ditunjukkan dalam QS. A li Imran [3]: 104 ("D an hendaklah ada di antara kamu segolongan umat yang menyeru kepada kebajikan, menyuruh kepada yang ma'ruf, dan mencegah dari yang munkar; merekalah orang-orang yang beruntung."), dan beberapa ayat yang lain: QS. Ali Imran [3]: 110, Q S. al-Nahl [16]:125, Q S. AI-M u'minun [23]: 73, dan laintain.

29 Sharan, B. M erriam \& Brockett, Ralph, G. The Profession and Practice of A dult Education: A n Introduction, (San Francisco, CA: Jossey-Bass, 2007), h. 7

30 Lihat A sep Shodiqin, "M embingkai 'E pisteme' IImu Dakwah", Jurnal IImu Dakwah, Volume 5 Nomor 2, 2011, h. 450 
31 Bandingkan dengan M. A min A bdullah yang menyitir hajat dasar manusia dalam konteks keilmuan, yaitu work (kerja), komunikasi, dan etika. Lihat M. A min A bdullah, Islamic Studies...,h. 389-398; Bandingkan juga dengan "type of human interest" yang terdiri dari kepentingan teknis, praktis, dan emansipatori, model $\mathrm{H}$ abermas. Lihat $\mathrm{F}$. Budi $\mathrm{H}$ ardiman, K ritik Ideologi: Pertautan Pengetahuan dan K epentingan, (Yogyakarta: Kanisius, 1990).

32 D alam pepatah bahasa orang-orang tua, sering disebut: kebutuhan sandang, pangan, papan, dan ditambah satu lagi, pasangan.

33 Lihat Aliyudin, "Prinsip-prinsip M etode D akwah M enurut AI-Q ur'an", Jurnal IImu Dakwah Volume 4, Nomor 15, 2010, h. 1007-1022

34 Bandingkan dengan ArisR isdiana, "Transformasi Peran D a'i dalam M enjawab Peluang dan Tantangan", Jurnal D akwah, Volume XV, N omor 2, 2014, h. 433451.

35 IImu dan ilmu agama seolah dua entitas yang berlainan dan terpisah satu sama lain, mempunyai wilayah masing-masing, baik objek formal-material keilmuan, metode penelitian, kriteria kebenaran, peran yang dimainkan oleh ilmuwan, bahkan ketingkat institusi penyelenggaranya. Lihat A min Abdullah, Islamic Studies..., h. 92.

36 Wan M ohd Nor Wan Daud, Filsafat dan Praktik Pendidikan Islam, terj. H amid Fahmy dkk. (Bandung: Mizan, 1998), h. 336

\section{DAFTAR PUSTAKA}

A bdullah, M. A min. 2006. Islamic Studies di Perguruan Tinggi: Pendekatan Integratifinterkonektif. Yogyakarta: Pustaka Pelajar.

A bdullah, M. Amin, 2014."Kontribusi Ilmu Kalam/Filsafat Islam dalam Pembangunan Karakter bangsa", IImu U shuluddin, Volume 13, Nomor 2.

Aliyudin, 2010."Prinsip-Prinsip M etode Dakwah M enurut AI-Q ur'an", Jurnal IImu Dakwah Volume 4, Nomor 15.

Allison, Henry E, 2008. C ustom and Reason in H ume, A K antian Reading of the First B ook of the Treatise, Oxford: Oxford U niversity Press.

al-Shâthiby, A bû Ishâq, al-M uwâfaqât min U sûl al-Sharî'ah, Kairo: Musthafâ Muhammad, tth.

Burgess, Steven, 2013."N ietzsche and H eidegger on the Cartesian Atomism of Thought" Dissertation U SA: U niversity of South Florida.

Daud, Wan Mohd Nor Wan, 1998. Filsafat dan Praktik Pendidikan Islam, terj. $\mathrm{H}$ amid Fahmydkk. Bandung: Mizan.

Drefcinski, Shane, "A Very Brief Summary of David Hume", dalam http:/ / people.uwplatt.edu/ drefcins/ humeen cyclopediaentry.html diakses Selasa, 26 Juli 2016 jam 05.00.

Guyer, Paul, 2009. Book Reviews "C ustom and Reason in Hume, A Kantian Reading of the First Book of the Treatise" dalam H ume Studies, Volume 35, Number 1,2.

$\mathrm{H}$ adiwiyono, $\mathrm{H}$ arun, 1980. Sari Sejarah Filsafat Barat 2, Yogyakarta: Kanisius. $\mathrm{H}$ ardiman, F. Budi, 1990. K ritik I deologi: Pertautan Pengetahuan dan K epentingan, Yogyakarta: Kanisius. 
Kartanegara, M ulyadhi, 2003. M enyibak Tirai K ejahilan, Pengantar E pistemologi Islam, Bandung: Mizan.

Lakatos, Imre, 1995. The M ethodology of Scientific Research Programmes, C ambridge: Cambridge U niversity Press.

Leibniz, G.W.F.,1960. "The Monadology," in The Rationalists, trans. George M ontgomery, N ew York: D oubleday.

Merriam, Sharan, B. \& Brockett, Ralph, G . 2007. The Profession and Practice of A dult E ducation: A n Introduction, San Francisco, CA: Jossey-Bass.

Muslih, Mohammad, 2014. Logika Ketuhanan dalam Epistemologi illuminasi Suhrawardi, Yogyakarta: Lesfi.

Poespoprojo, W., 1999. Logika Scientifika, Pengantar D ialektika dan IImu, Bandung: Pustaka G rafika.

Porter, N oah, ed., 1913. "E pistemology". W ebster's Revised U nabridged D ictionary, $G \& C$. Merriam C 0 .

Psillos, Stathis, and M artin Curd, 2010. The Routledge Companion to Philosophy of Science 1. publ. in paperback ed., London: Routledge.

Risdiana, A ris, 2014. "Transformasi Peran Da'i dalam M enjawab Peluang dan Tantangan", Jurnal D akwah, Vol. XV, No. 2.

Rolston, III, Holmes, 1987. Science and Religion: A Critical Survey, N ew York: Random H ouse, Inc.

Shodiqin, Asep, 2011. "M embingkai 'Episteme' IImu Dakwah", Jurnal IImu Dakwah, Volume 5, Nomor 2.

Sunardi, St., 2011. N ietzsche, Yogyakarta: LKiS.

Suriasumantri, Jujun S. 1990. Filsafat IImu Sebuah Pengantar Populer. Jakarta: Sinar H arapan.

Tjahjadi, Simon Petrus L,2007. Tuhan Para Filsuf dan IImuwan, Yogyakarta: Kanisius.

W ebster's N ew World Dictionary of the A merican Language, 1962. (Cleveland and N ew York: The World Publishing Company.

QS. Ali Imran [3]: 110.

QS. Al-Nahl [16]:125.

QS. Al-M u'minun [23]: 73.

QS. al-An'am [6]: 162-163.

QS. al-Baqarah [2]: 112, QS.

AI-D zariyat [51]: 56, QS.

Al-M ujadilah [58]: 11.

Shahih Sunan al-Turmudziy: 1610.

Shahih al-A dab al-M ufrad: 237.

Shahih al-Jami' al-Shaghir: 5381.

Silsilah al-A hadits al-Shahihah: 320.

Sunan Baihaqi: 20571. 
